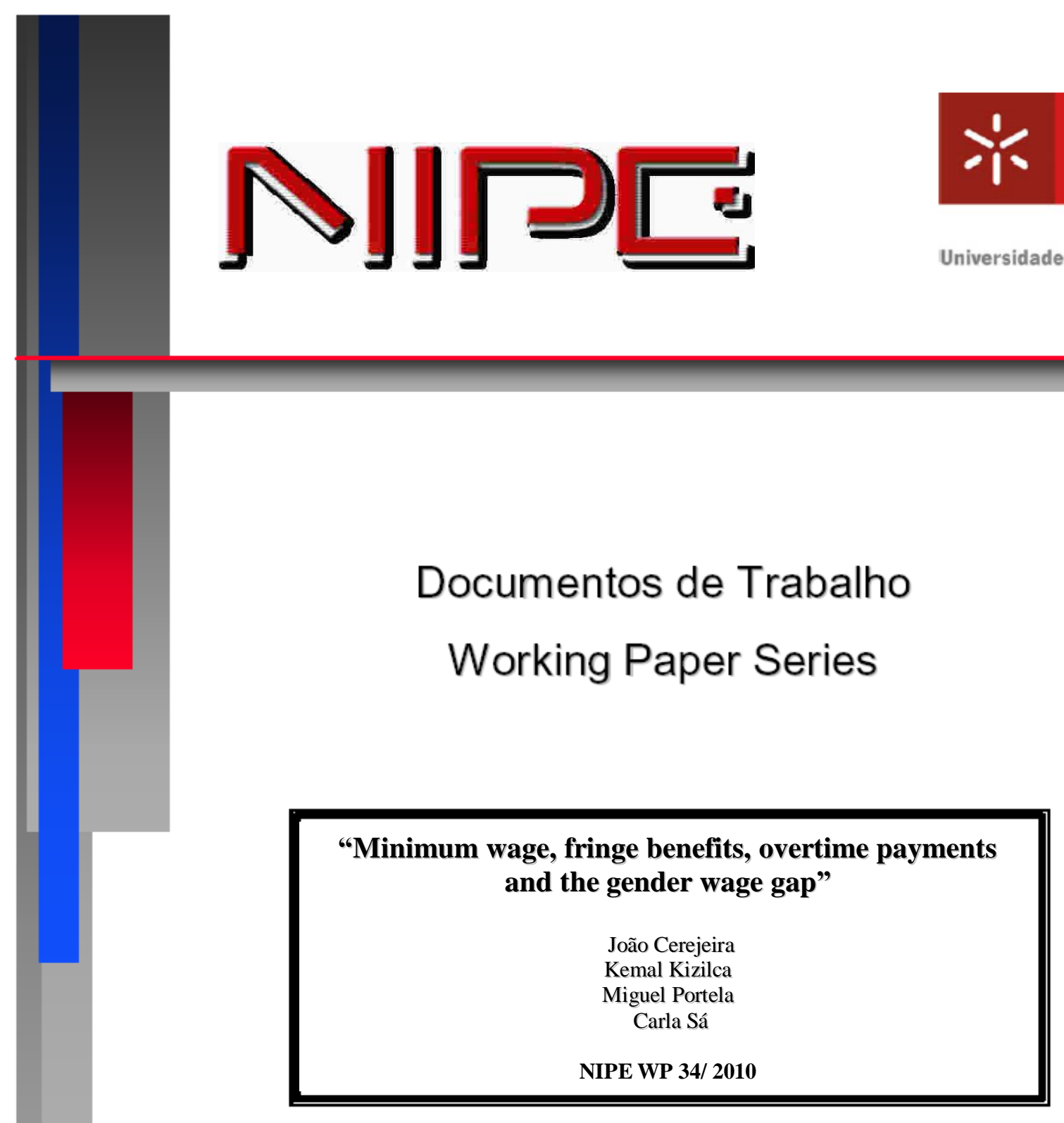

NÚCLEO DE INVESTIGAÇÃO EM POLÍTICAS ECONÓMICAS UNIVERSIDADE DO MINHO 


\section{"Minimum wage, fringe benefits, overtime payments and the gender wage gap"}

João Cerejeira

Kemal Kizilca

Miguel Portela

Carla Sá

NIPE ${ }^{*}$ WP 34/ 2010

URL:

http://www.eeg.uminho.pt/economia/nipe

* NIPE - Núcleo de Investigação em Políticas Económicas - is supported by the Portuguese Foundation for Science and Technology through the Programa Operacional Ciência, Teconologia e Inovação (POCI 2010) of the Quadro Comunitário de Apoio III, which is financed by FEDER and Portuguese funds. 


\title{
Minimum wage, fringe benefits, overtime payments and the gender wage gap *
}

\author{
João Cerejeira ${ }^{\dagger}$ Kemal Kızılca ${ }^{\ddagger}$ Miguel Portela ${ }^{\S}$ Carla Sá
}

February 16, 2012

\begin{abstract}
Using linked employer-employee data for Portugal, we explore an amendment to the minimum wage law which increased from $75 \%$ to $100 \%$ of the full minimum wage applied to employees younger than 18. Our results show a widening of the gender wage gap following the amendment: the wage gap for minors increased 2.7 percentage points more than for other groups. This change was mainly determined by a redistribution of fringe benefits and overtime payments. We discuss three possible sources of redistribution: (i) a change in the skill composition of the working males and females after the increase in the minimum wage, (ii) industrial differences in response to the changes in the wage floor, and (iii) discrimination. Estimations support the second channel as the main contributing factor, while possible discrimination effects cannot be eliminated.

Keywords: minimum wage, overtime payments, fringe benefits, gender wage gap, minors

JEL-codes: J31, J32, J71

${ }^{*}$ This research was funded by the Portuguese National Science Foundation under project grant FCOMP-01-0124-FEDER-007218. We are grateful to Ana Rute Cardoso and to the participants at NIPE - Universidade do Minho seminar, the $6^{\text {th }}$ ZEW Workshop, the $4^{\text {th }}$ Meeting of the Portuguese Economic Journal, and the Workshop "Economic analysis using linked employer and employee data: bringing together theory and empirics", for their helpful comments. We thank the Ministry of Solidarity and Social Security, Statistics Department, for having provided the data.

${ }^{\dagger}$ University of Minho and NIPE. Corresponding author. Address: Universidade do Minho, Departamento de Economia, Gualtar, 4710-057 Braga, Portugal. E-mail: jccsilva@eeg.uminho.pt.

¥NIPE and Ankara University. E-mail: kkizilca@law.ankara.edu.tr.

§University of Minho, NIPE and IZA. E-mail: mangelo@eeg.uminho.pt.

『University of Minho, NIPE and CIPES. E-mail: cangelica@eeg.uminho.pt.
\end{abstract}




\section{Introduction}

Does a minimum wage increase close the gender wage gap? Empirical evidence shows that changes in minimum wages tend to have a larger impact on individuals at the bottom of the wage distribution, namely young workers and females. Therefore an increase in the existing minimum wage level might reduce the wage gender gap as wages of females increase more than wages of males. However, the impact on the gap may be ambiguous, if fringe benefits and overtime payments - which are usually not regulated by the law - are redistributed following a minimum wage increase.

Several studies have discussed whether employers reduce pecuniary and non-pecuniary benefits (e.g. health insurance, pension plan, meals, transportation, paid vacation, accommodation and on-the-job training) as a response to a rise in the minimum wage (Card and Krueger, 1995; Simon and Kaestner, 2004). The distribution of these benefits is not necessarily gender-neutral. Furthermore, studies on the American labor market find that women are concentrated in occupations where fringe benefits are higher (Averett and Hotchkiss, 1995; Solberg and Laughlin, 1995; Lowen and Sicilian, 2009). These studies suggest that the gender wage gaps within occupations are - at least partially - explained by women's higher probability of receiving fringe benefits. A natural outcome of joint evaluation of these two bodies of literature is that, if a minimum wage increase affects the extra components of income, the gender gap at the base wage and for the total payments may be affected in different directions, depending on the gender redistribution of benefits.

In this paper, we investigate the effect of a minimum wage increase on the gender gap at various levels of employee compensation, namely, base wage, fringe benefits, overtime payments and overtime hours. We further explore the possible channels through which the change in the minimum wage may affect the gender gap on the base wage and the extra income components in different directions. In doing so, we explore the effect of the 1998 amendment of the Portuguese minimum wage law, which increased its level for employees younger than 18 years of age from $75 \%$ to $100 \%$ of the full minimum. Such change in the legislation targeting a specific group of employees provides a natural experiment environment, which allows for disentangling the minimum wage effects from 
the effects of other variables. In our analysis we use linked employer-employee data for the Portuguese labor market, which provides detailed information on the extra components of income at individual level.

To our knowledge, there is no other study investigating whether a rise in the minimum wage level results in a redistribution of fringe benefits among different groups of employees. Redistribution may arise from reasons such as industry or occupation differences in flexibility of fringe benefits with respect to a rise in the wage floor, employers' willingness to keep the wage hierarchy among workers with different characteristics, or discrimination. On the other hand, employers may not be able or willing to cut/redistribute benefits for several reasons: the eventual decrease in worker productivity due to lower incentives may be higher than the reduction in benefits; or it could be impossible to reduce benefits of a particular group of employees, due either to the nature of the working conditions or to legal reasons; or simply because the existing amount of benefits may not be high enough to allow adjustments (Holzer, Katz and Krueger, 1991; Simon and Kaestner, 2004).

The paper proceeds as follows. The next section reviews the empirical evidence on the topic. Section 3 presents the data used and the wage distributions for minors and adults. The impact of the minimum wage increase on different wage components and on the gender gap is analyzed on Section 4. Section 5 discusses robustness checks for the main results, while Section 6 explores some possible channels of labor earnings redistribution in response to minimum wages legislation changes. Finally, Section 7 concludes.

\section{The minimum wage, benefits and the gender wage gap: channels of transmission}

There is some evidence in the literature regarding the fact that the minimum wage (MW), affecting the individuals at the bottom of the wage distribution, tends to have a larger impact on youngsters and females. The introduction of a MW law, or any increase in the existing MW level, will then reduce the gender gap as long as more 
women remain at the lower tail of the wage distribution than men.

Nevertheless, the impact of minimum wage laws on gender gap remains less explored. In one of the few studies filling that gap in the literature, Meyer and Wise (1983) conclude that women are more likely to become unemployed following the introduction of MW. Shannon (1996) extends their analysis to measure the impact of MW on the gender wage gap and observes a reduction of the gap following its introduction, which he attributes to adverse unemployment effects on females. Robinson (2002) investigates the impact of the introduction of MW on the gender wage gap in Britain. She concludes for a moderate effect of the MW, which may result from the low level of the introduced MW. In her following study, Robinson (2005) investigates the effect of the MW for British regions. Her findings show that the larger the share of women among low paid workers in a region and the longer the regional distance between the MW and the average wage before its introduction, the bigger the reduction in the gender pay gap after the introduction of the MW.

The gender gap is also likely to occur at the extra components of income, not covered by MW laws. ${ }^{1}$ An important issue is whether or not firms respond to the MW by adjusting fringe benefits. There are studies that found a negative impact of MW on fringe benefits (Wessels, 1980; Sicilian and Grossberg, 1993). On the other hand, later studies usually conclude that increases in MW are not offset by reductions in fringe benefits (Card and Krueger, 1995; Simon and Kaestner, 2004; Grossberg and Sicilian, 2004).

Depending on the flexibility of the extra components of worker compensation with respect to changes in the base wage, a MW increase also has the potential to increase the gender gap at the total wage level, through redistribution of fringe benefits and overtime payments. This may occur through various channels. ${ }^{2}$ Firstly, if the employer has a discriminatory taste, discrimination on labor compensation could occur at extra income components for the minimum wage earners, assuming that there is compliance with the law. Employers may exploit the window between the MW and overtime payments,

\footnotetext{
${ }^{1}$ There are few studies based on the U.S. labor market that investigate the relationship between fringe benefits and the gender wage gap (Averett and Hotchkiss, 1995; Solberg and Laughlin, 1995; Lowen and Sicilian, 2009). The common implication of these studies is that the gender gap becomes smaller when the distribution of benefits is accounted for.

${ }^{2}$ We do not assert that these explanations are exhaustive.
} 
which are usually higher than the payments for normal hours. The discrimination could arise either by paying different overtime hourly wages or by redistributing overtime hours between male and female workers, according to his discriminatory preferences. Another possibility is the discrimination on the provision of fringe benefits. A MW increase, then, may result in a wider gender gap at the total wage level if the gap on fringe benefits is rising faster than the reduction in the gap on the base wage. ${ }^{3}$

A second channel is the change in the skill composition of the workforce as a result of a MW increase. Some recent studies assert that MW may result in an increase in both the supply of and the demand for high-skilled labor. According to these studies, the resulting substitution from low- to high-skilled workers masks the unemployment effect of the MW for the low-skilled ones (Ahn, Arcidiacono and Wessels, 2011; Cerejeira, 2008; Giuliano, 2011). If, as a result of a rise in the MW, high skilled male workers increase their supply of labor, while the females do not respond in the same proportion, there may be a change in the skill composition and the resulting wage gap may be reflecting the productivity differences.

Industry and/or occupation differences in the flexibility of fringe benefits with respect to the changes in the MW level may act as a third channel for creating a gender gap. This occurs when fringe benefits provided in industries or occupations where females are concentrated are easier to adjust compared to the others. Differences across industries in mark-ups may also affect the flexibility of the benefits. In industries where prices are competitively determined, employers may respond to the increases in wage costs by reducing extra payments. On the other hand, in less competitive industries, namely in non-tradable goods sector, employers may prefer to adjust mark-up ratios if reducing extra payments have productivity costs.

Summing up, empirical evidence on the role of MW in narrowing the gender wage gap is rather moderate. The few existing papers on the subject only examined the gender gap for the base wages, while the gap is likely to differ in the extra components of income. Depending on the flexibility of extra income components with respect to changes in the MW, the gap at the base and full wage level may change in different

\footnotetext{
${ }^{3}$ The existence of and compliance with non-discriminatory laws on fringe benefits may also be effective in the gender gap.
} 
directions. The present paper adds to the literature by analyzing the effect of the MW on gender wage gap and how it relates to fringe benefits and overtime payments.

\section{$3 \quad$ The Portuguese setting}

\subsection{Context and data}

Since 1974, when the MW was first introduced, Portugal moved from an initial stage with several exemptions to the full minimum depending on the age of the worker, the sector, and the firm size, to a stage where almost all workers are entitled to it. There have been several amendments to the law that brought to an end the exemptions. ${ }^{4}$ As of 1997, there were different MW levels applied to minors (workers younger than 18 years of age), apprentices and all the other employees: the minors and the apprentices (regardless of their age) were entitled to $75 \%$ and $80 \%$ of the full MW, respectively. A change in the law in August 1998 increased the minors' MW to the full minimum wage. This meant a 33\% further increase in their MW compared to adults. This amendment was part of a series of legislation changes aiming at applying a single MW law to all Portuguese employees and therefore is likely to have been exogenous with respect to labor market conditions.

Our analysis benefits from the quasi-natural experiment environment created by the 1998 change, as well as from a comprehensive linked employer-employee data set on the Portuguese labor market: 'Quadros de Pessoal' $(Q P)$. The Portuguese Ministry of Labour and Social Solidarity (MTSS) collects these data through an yearly questionnaire, which is mandatory for all firms with at least one employee. It includes information on firms (such as location, industry, sales, number of employees, date of constitution, legal setting, ownership type), its establishments and all its wage earners (e.g. gender, age, education, hours of work, labor earnings, date of admission into the firm). Civil servants and domestic service workers are not covered, and the coverage of sectors such as fisheries and agriculture is low given its low share of wage-earners.

$Q P$ contains four different wage categories: (i) base wage; (ii) overtime payments;

\footnotetext{
${ }^{4}$ See Almeida (2008) for a list of amendments in the MW law since 1974.
} 
(iii) regular benefits, which may include meal plans, transportation, accommodation, as well as compensations for seniority, productivity, attendance, hazardous work, nightshift; and (iv) any irregular benefits such as distributed profits, stock shares, Christmas subsidies paid in advance, among others. As the MW law regulates only the first category, an additional wage gap is likely to occur at the remaining payment components. ${ }^{5}$ Due to data limitations we are not able to extend our analysis to the effect of MW on on-the-job training, neither do we conduct any analysis on the effects on health insurance and pensions since the contributions that have to be made by workers and firms are explicitly defined by law. It is also worth mentioning that the MW is set for monthly wages, but the law includes a formula for the calculation of the MW for those who work less than the contractual hours. ${ }^{6}$ These may include, among others, employees with part-time contracts and absentees for reasons such as sickness.

The 1998 amendment was implemented in August, while the data on yearly $Q P$ questionnaires refer to October. These dates are important for our analysis, as the decisions about schooling were already made and contracts for summer jobs were already ended by the time the firms filled in the questionnaires. This means that our results are not driven by the changes in employment caused by schooling decisions and temporary jobs.

In 1997, the year before the amendment, the share of minor employees among the total labor force was only $0.7 \%$ (see Table 1). This small share of minors is the reason why we do not expect the amendment to have any spillover effect on any other age group in the labor market. The shares of females among adult and minor employees were $40.7 \%$ and $43.8 \%$, respectively. The share of females among adult employees increased over time, while the trend ran in the opposite direction for minors. Because of increasing schooling, the employment of minor females have been decreasing as opposed to their adult counterparts. Their working hours have been decreasing as well, faster than for any other group in the workforce. This general trend in employment for minors - and particularly for minor females - prevents us from drawing any conclusions on the

\footnotetext{
${ }^{5}$ Given the higher level of payments for overtime hours, there has always been a window of adjustment for this payment category.

${ }^{6}$ The formula is $H M W=(M W * 12) /(C W H * 52)$, where $H M W$ is hourly MW, and $C W H$ stands for contractual weekly working hours at industry level.
} 
employment effects of the MW increase in 1998.

Table 1: Shares of minors and females

\begin{tabular}{|c|c|c|c|}
\hline & \multirow{2}{*}{$\begin{array}{c}\text { All } \\
\text { Minors } \\
(1)\end{array}$} & \multicolumn{2}{|c|}{ Females } \\
\hline & & $\begin{array}{l}\text { Adults } \\
\qquad(2)\end{array}$ & $\begin{array}{c}\text { Minors } \\
\text { (3) }\end{array}$ \\
\hline 1995 & 0.009 & 0.397 & 0.455 \\
\hline 1996 & 0.007 & 0.402 & 0.446 \\
\hline 1997 & 0.007 & 0.407 & 0.438 \\
\hline 1998 & 0.006 & 0.411 & 0.432 \\
\hline 1999 & 0.005 & 0.418 & 0.426 \\
\hline 2000 & 0.005 & 0.421 & 0.417 \\
\hline 2002 & 0.004 & 0.419 & 0.397 \\
\hline 2003 & 0.003 & 0.425 & 0.379 \\
\hline 2004 & 0.003 & 0.426 & 0.376 \\
\hline 2005 & 0.004 & 0.432 & 0.382 \\
\hline 2006 & 0.003 & 0.437 & 0.378 \\
\hline 2007 & 0.003 & 0.441 & 0.390 \\
\hline \multicolumn{4}{|c|}{$\begin{array}{l}\text { Notes: (1): share of minor employees } \\
\text { among the total labor force. ( } 2 \text { ): share } \\
\text { of female employees among the adult } \\
\text { labor force. (3): share of female em- } \\
\text { ployees among the minor labor force. } \\
\text { Source: own computations based on } \\
\text { Portugal, MTSS ( } 1995 \text { to } 2007) \text {. }\end{array}$} \\
\hline
\end{tabular}

\subsection{Evidence on wages}

Figure 1 shows the distributions of wages for adults by gender for the period 19971999, which encompasses the year the amendment took place. The patterns of the distributions in these selected years give us the general picture of the gender wage gap and how it is affected by the MW, in the Portuguese economy. The mode wage of males is higher than the MW, which is also close to the level where the distribution for females has a second spike. Males are visibly more concentrated at higher wage levels. 
The wages at the lower tail of the distribution, which are swept up to the MW, are mostly female wages. This suggests the equalizing impact of MW at the adult level.

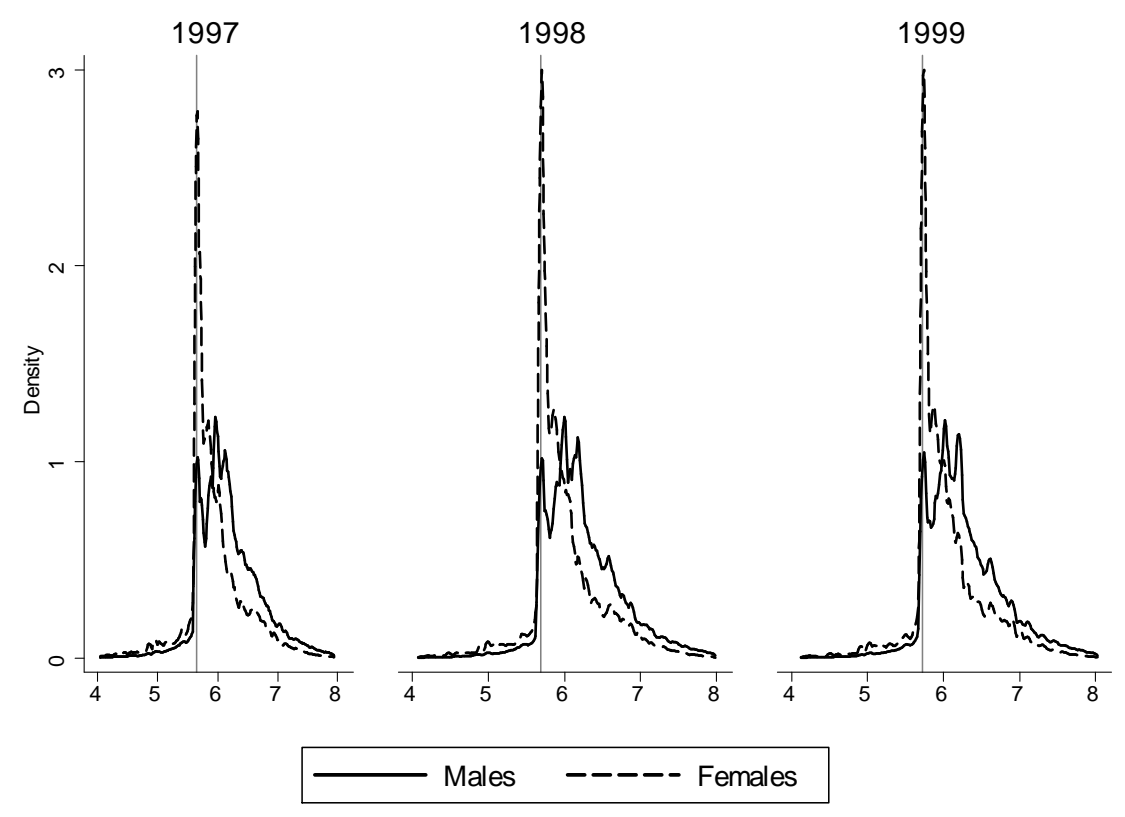

Figure 1: Wage distributions for adults. Notes: The vertical line indicates the minimum wage. Figures refer to log nominal monthly base wage in Euros. Employees earning less than $20 \%$ and more than 10 times of the minimum wage are excluded from the density graphs to keep the tails short. Source: own computations based on Portugal, MTSS (1995 to 2007).

Figure 2 replicates Figure 1 for minors. Wage distributions for minor males and females do not differ substantially before 1998. The two spikes in both the 1997 and 1998 graphs correspond to $75 \%$ and the full MW levels, respectively. This indicates that a considerable fraction of minors were still earning pre-legislation wages in $1998 .^{7}$ Since the amendment passed in August, and until that month minors were entitled for $75 \%$ of the minimum, it is highly probable that in October - the month for which the questionnaires were filled in -, some firms reported pre- and others post-legislation wages. The switch between the heights of the $75 \%$ and $100 \%$ level spikes from 1997 to 1998 is in line with this explanation. After 1998, the lower spike shifts to the $80 \%$ level, which was applied to apprentices. ${ }^{8}$

\footnotetext{
${ }^{7}$ It is also notable from the graphs that, although it was not a binding wage floor for minors before 1998, employers paid the full MW to a high fraction of this age group - possibly showing a numéraire effect of the minimum wage.

${ }^{8}$ Before 1998, the MW for apprentices was binding for the adult employees only.
} 


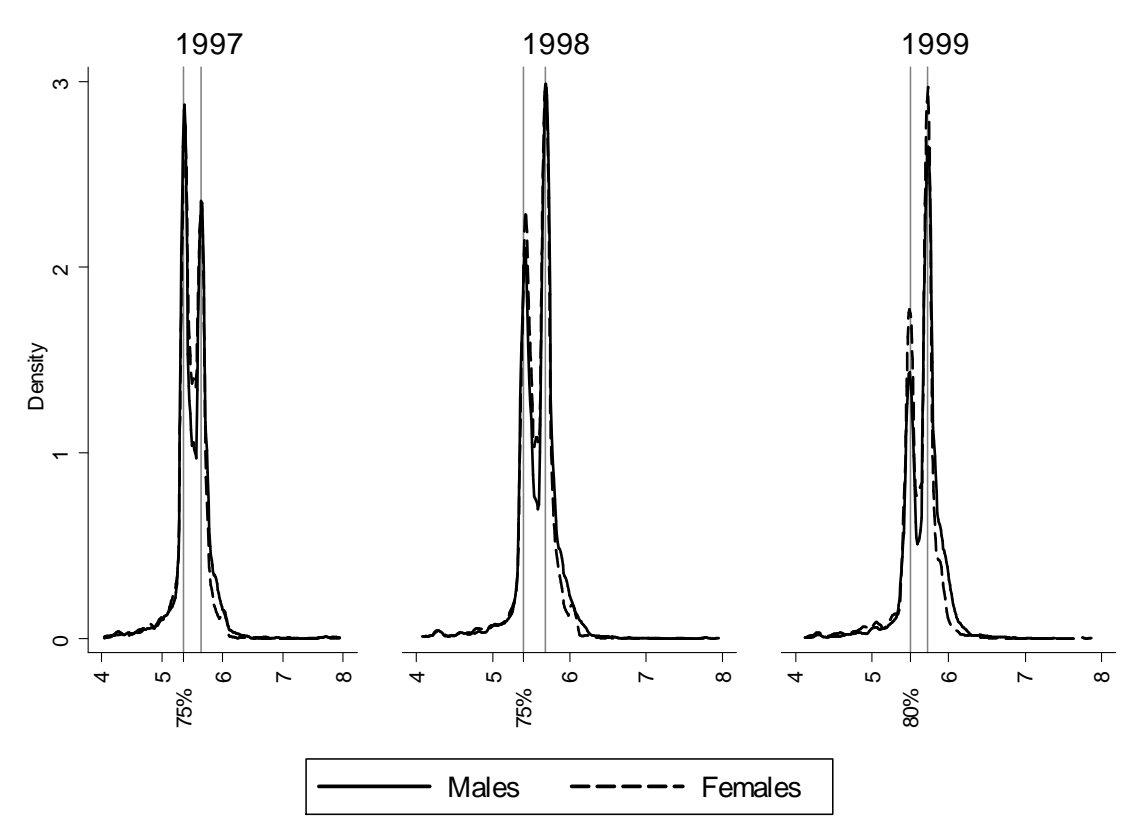

Figure 2: Wage distributions for minors. Notes: The first vertical line indicates MW for minors in 1997 and beginning of 1998 and MW for apprentices in 1999. The second vertical line in each graph indicates the full minimum wage. Figures refer to log nominal monthly base wage in Euros. Employees earning less than $20 \%$ and more than 5 times of the minimum wage are excluded from the density graphs to keep the tails short. Source: own computations based on Portugal, MTSS (1995 to 2007).

The spikes in these wage distributions show that there has been compliance with the MW law, and the MW level has been binding - especially - for minors and female adults. The effect of the 1998 amendment on the distribution of wages for the minors is also apparent. Male and female wage distributions for minors before 1998 overlap almost perfectly. As such, we do not expect an equalizing effect from an increase in the MW, but can it bring up a gender wage gap? We seek for this line of answers in the following sections.

\subsection{The wage gap over time}

We now analyze the gender wage gap in Portugal and its evolution over time. We limit the analysis to the post-1995 period, considering that several changes in the legislations on schooling, as well as MW for teenagers, took place before that date, which were expected to affect labor market equilibrium for minors. After 1995, however, mandatory schooling duration remained the same. The only change in the MW law which might 
affect minors was the one which occurred in 1998.

In order to characterize the wage gap over time we estimate the following wage equation:

$$
\mathrm{W}_{i t}=\beta_{0}+\beta_{1} \mathrm{FEMALE}_{i}+\beta_{2 t} \mathrm{YEAR}_{t}+\beta_{3 t} \mathrm{FEMALE}_{i} \times \mathrm{YEAR}_{t}+\beta_{4} \mathrm{X}_{i t}+\varepsilon_{i t},
$$

where $\mathrm{W}_{i t}$ is $\log$ hourly real wage, $\mathrm{FEMALE}_{i}$ is a dummy variable taking the value 1 for females, $\mathrm{YEAR}_{t}$ is a set of year dummy variables; $\mathrm{X}_{i t}$ is a vector of control variables including education, experience and its square, the log firm size, dummies for occupation, industry classification, and firm location; $i$ stands for individual and $t$ stands for year (1995-2007). ${ }^{9}$ We estimate this equation for alternative age groups, as well as for base wages and total wages, separately. The coefficient of $\mathrm{FEMALE}_{i}, \beta_{1}$, gives the wage gap for 1995, which is the baseline year; $\beta_{2 t}$ is the estimate for the yearly changes in real wages compared to $1995 ; \beta_{3 t}$ captures the change in the wage gap relative to the baseline year.

Figure 3 shows the estimation results for the gender wage gap for alternative age groups and wage definitions. ${ }^{10}$ In each group the solid and the dashed lines show the gender gap at the full wage and the base wage levels, respectively. It is clear that, in Portugal, the gender gap is systematically higher at the full wage level. This observation contrasts with findings based on the U.S. data. For adults, the gap is approximately 5 percentage points higher at the total wage, while the difference is smaller, but more volatile, for minors. The previously mentioned differences in the laws regulating the provision of pension plans and health insurances are the most probable reasons for this reversal between the two countries. In Portugal, all firms are obliged to pay the same tax rate to cover these benefits, regardless of the industry and occupation of the worker, and these contributions are not accounted in the $Q P$ database. Therefore, this eliminates the possibility of any gender bias in receiving these benefits caused by industrial or occupational crowding. Figure 3 also shows that the gender gap increases with age. $^{11}$

\footnotetext{
${ }^{9}$ Data for workers for the year 2001 was not made available by MTSS.

${ }^{10}$ The tables with the corresponding estimation results are available from the authors upon request.

${ }^{11}$ We include potential experience as regressor, which also accounts for age. Thus, it might be the
} 


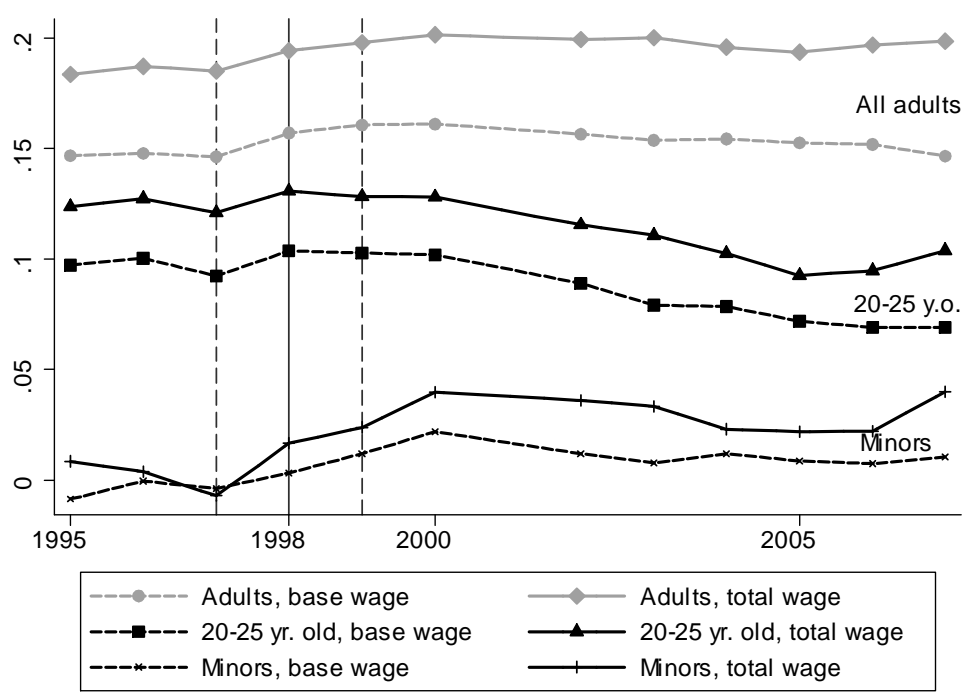

Figure 3: Hourly adjusted gender wage gap. Notes: The underleying regressions are defined by equation (1) and include, as control variables, education, experience and its square, log firm size, and dummies for occupation, industry and firm location. Source: own computations based on Portugal, MTSS (1995 to 2007).

Our main interest lies on the change in the gender gap for minors after the amendment. The coefficients for FEMALE $\times$ YEAR for the pre-amendment period are all statistically insignificant and close to zero at both the base and the full wage levels for minors; i.e., there was no average gender gap at ages below 18 years. However, there is a visible widening of the hourly-wage gap following 1998, particularly for total wages: the gap increased from $-0.07 \%$ in 1997 to $1.9 \%$ in 1998 and further to $2.5 \%$ in 1999 .

A question emerges: how much of this widening can be explained by the increase in the MW? To answer this question, we compare the increase in the gap for minors and for our control group, 20-25 year old employees. The adjusted hourly-wage gap for the 20-25 years old employees was stable around $12 \%$ during this period, while the gap on the base wage increased around one percentage point. The gap for the whole adult group also shows a small increase. The difference between the paths of the wage gap for the minor and the other employees following the amendment is striking: within two years the gap for minors increased about three percentage points more than the gap for case that it is not the age that is correlated with the gap, but possibly the wage level itself, which also increases with age. Arulampalam, Booth and Bryan (2007), among others, provide convincing evidence on increasing gender gap at the higher tail of the wage distribution. 
other groups, which is substantial considering the insignificant wage gap prior to the amendment.

In the remaining parts of the paper we seek answers to the following questions. First, is the difference between the changes in the gap for minors and the others after the amendment statistically significant? Second, if that is the case, in which components of total wage did the differentiation occur? Third, what is the impact of the MW increase on overtime payments and benefits?

\section{The impact of the minimum wage increase on dif- ferent wage components and the gender gap}

As the wages are set on an yearly basis in Portugal and the data reports to October, some of the employers would be paying pre-amendment wages until October 1998. Therefore, we do not expect to fully observe the effect of the amendment on the wage distributions before 1999 (see Figure 2). To account for the delayed effects, we estimate a wage equation for the 1997-1999 period, including the year of the amendment, one year before and one year after the amendment and combining adults and minors. ${ }^{12}$ As such, the empirical procedure is a difference-in-difference-in-differences (DDD) setting that compares the wages of males and females, minors and adults, before and after the amendment:

$$
\begin{aligned}
& \mathrm{W}_{i t}=\beta_{0}+\beta_{1} \operatorname{MinOR}_{i}+\beta_{2} \mathrm{FEMALE}_{i}+\beta_{3} \mathrm{AFTER}_{t} \\
& +\beta_{4} \operatorname{MinoR}_{i} \times \text { Female }_{i}+\beta_{5} \operatorname{Minor}_{i} \times \operatorname{AFteR}_{t}+\beta_{6} \text { Female }_{i} \times \text { AFter }_{t} \\
& +\beta_{7} \mathrm{FemAlE}_{i} \times \operatorname{MinOR}_{i} \times \operatorname{AFteR}_{t}+\beta_{8} \mathrm{X}_{i t}+\varepsilon_{i t} .
\end{aligned}
$$

In this setting, Minor is a dummy variable taking the value 1 if the employee is younger than 18 years of age, AFTER is the period dummy, which is 1 for 1998 and after, while the other elements of equation (2) are the same as in equation (1). The estimates for the gender wage gap before the amendment for adults and minors are $\beta_{2}$ and $\beta_{2}+\beta_{4}$,

\footnotetext{
${ }^{12}$ See Neumark and Wascher (2007) for a summary on the discussion of the delayed effects of the minimum wage.
} 
respectively. The wage increase for male adults between the two periods is captured by $\beta_{3}$. The coefficient on FEMALEXAFTER compares the gender gap for adults before and after the amendment, while the analogous difference for minors is captured by $\beta_{6}+\beta_{7}$. The main coefficient of interest is $\beta_{7}$, which compares the increases in the wage gap of minors and the control group, adults. ${ }^{13}$ Therefore, the DDD estimator compares the changes in the wage gap for minors with the same change for adults.

A usual concern in DDD analyses is the choice of the control group as a proper reference. The control group is expected both to be immune to the effect of policy change and have a similar trend for the variable of analysis in absence of the treatment. The very small share $(0.7 \%)$ of the minor employees in 1998 makes it very unlikely that the amendment had any ripple effects on the rest of the labor force. Thus, we expect any sub-group of the adult labor force to fulfill the first condition.

However, regarding the long-term trends in the gender gap, there are some differences among age groups. The gap is relatively volatile at younger age groups compared to the adults (see Figure 3). Thus, choosing the whole adult cohort as the control group has a potential to produce spurious results in a DDD setting. To eliminate this possibility, we have chosen the employees of 20-25 years of age as the control group, which also has a similar trend as the minors in the absence of a policy change. ${ }^{14}$

Table 2 reports the estimation results for alternative payment categories and Table 3 reports the estimation results for overtime hours. Because all dependent variables in the payment equations are in logs, employees receiving zero overtime payment and/or benefit are dropped from the respective equations and this justifies the differences in the number of observations across sets of results. Thus, besides measuring the effect

\footnotetext{
${ }^{13}$ In an alternative expression, $\beta_{7}$ gives us the following:

$[E(\mathrm{~W} \mid \mathrm{Female}=0$, Minor $=1$, After $=0, X)-E(W \mid \mathrm{Female}=1$, Minor $=1$, After $=0, \mathrm{X})]$

$-[E(\mathrm{~W} \mid \mathrm{Female}=0$, Minor $=1$, After $=1, X)-E(W \mid \mathrm{Female}=1$, Minor $=1$, After $=1, \mathrm{X})]$

$-\{[E(\mathrm{~W} \mid \mathrm{Female}=0$, Minor $=0$, After $=0, X)-E(W \mid$ Female $=1$, Minor $=0$, After $=0, X)]$ $-[E(\mathrm{~W} \mid \mathrm{Female}=0, \operatorname{Minor}=0, \operatorname{After}=1, X)-E(W \mid \mathrm{Female}=1, \operatorname{Minor}=0, \operatorname{After}=1, \mathrm{X})]\}$
}

where the first term is the wage gap before 1998 for minors and the second term is the wage gap for 1998 and 1999 for minors. The difference between them is the change in the wage gap for minors. Finally, the third term is the change in the gap for adults.

${ }^{14}$ It is possible to create almost an infinite number of alternative control groups among the adult employees. We should note that in a number of experiments we conducted with different control groups we achieved similar results for the main effect we discuss. See the robustness checks for further discussion on this issue. 
on the gender wage gap for those earning positive overtime payments and benefits, it is also important to control for selection bias related to the probability of receiving these extra incomes. Results based on Heckman selection regressions are shown in columns (3) and (4) of Table 2 for overtime payments, and in columns (6) and (7) for benefits, in the same table.

The selection equation requires the inclusion of some variables that affect the chance for overtime work or receiving benefits but not the wage. The variables chosen are the share of workers older than 25 years that worked overtime within the firm, for the overtime selection equation (\% OverTime $\left.\operatorname{HouRS}_{t-1}\right)$, and the share of workers older than 25 years that received any kind of benefits within the firm, for the benefits selection equation $\left(\%\right.$ BENEFITS $\left._{t-1}\right)$. The rationale behind the choice of these variables is based on the assumption that using overtime work and benefits payments are not only related with worker characteristics but also with the firm strategy concerning human resources management. We expect that workers employed in firms that make greater use of overtime work and of benefits payments have more probability of work overtime or receive benefits. We opt for including the (one year) lag of those variables in order to reflect long-run firm policies and not short-run demand shocks.

The coefficient of FEMALE $\times$ MINOR $\times$ AFTER is significant and negative for all wage definitions, except for the base wage. The result for the base wage is something we would expect as the law regulates this category. However, for overtime payments and fringe benefits, there are relevant increases in the gender gap. For overtime payments, the increase is 26 percentage points. However, its effect on the gender gap for the total wage should be relatively small, concerning the small share of minors working extra hours (see Table 10). There is also an increase of about 5.2 percentage points in the gender gap regarding fringe benefits for minors, but it is not statistically significant at $10 \%$ significance level. Overall, we observe a 2.7 percentage points increase in the total hourly gender pay gap for minors between 1997 and $1999 .{ }^{15}$

\footnotetext{
${ }^{15}$ Computations based on monthly wages reinforce these conclusions - see Table 12.
} 


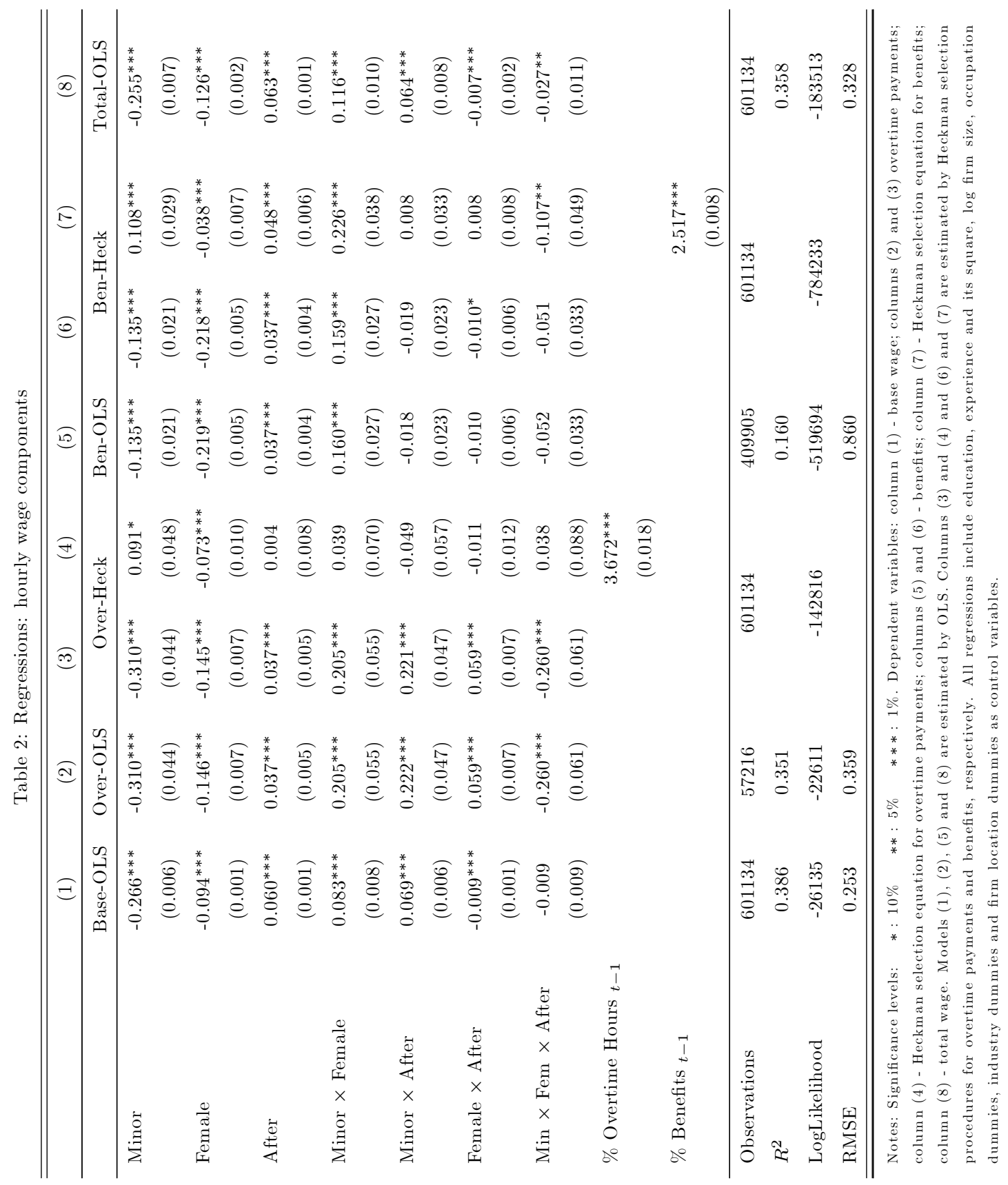


The Heckman selection results for overtime payments, Table 2, column (4), indicate that our additional variable in the selection equation is statistically significant. However, a Wald test for the independency of the equations does not reject the null hypothesis, ${ }^{16}$ and therefore the results for the OLS and Heckman model are virtually the same (columns (2) and (3)). Looking to the Heckman model for benefits, columns (6) and (7), we conclude that the additional variable in the selection equation is statistically significant at the $1 \%$ significance level. We now reject the independency between the main equation for benefits and the selection equation. ${ }^{17}$ It is particularly interesting with this last result that the coefficient for the triple interaction, $-0.107,{ }^{18}$ is statistically significant at the $5 \%$ significance level: female minors became less likely to receive benefits.

Despite the redistribution of benefits and overtime payments against the minor females after the amendment, their adjusted hourly real total wage increased around 3.7 percentage points further than the adult females $\left(\hat{\beta}_{5}+\hat{\beta}_{7}\right)$. The analogous increase for the minor males was 6.4 percentage points $\left(\hat{\beta}_{5}\right)$. In other words, the reduction/redistribution of fringe benefits was not large enough to dominate the increase of the base wage of both male and female workers. This result is in line with abovementioned studies which found limited effect of MW on reductions of the fringe benefits.

The increase in the gender gap for overtime payments could be explained by changing overtime hourly wages or by redistributing overtime hours. We explore these hypothesis running a set of regressions, using OLS and count data models (Tobit and NegativeBinomial), which allow for a large number of zero observations and for a small set of discrete values for the dependent variable (number of hours). Results are presented in Table 3.

The marginal effect of MIN $\times$ FEM $\times$ AFTER shows that there are no significant decrease in the quantity of overtime worked hours for minor females after amendment compared with minor males. Looking at column (4), Table 3, we observe that the es-

\footnotetext{
${ }^{16}$ We have a $\chi_{(1)}=1.75$ test statistic, with a corresponding $p$-value of 0.1859 .

${ }^{17}$ We have a $\chi_{(1)}=20.19$ test statistic, with a corresponding $p$-value of about 0 .

${ }^{18}$ The marginal effect is about -2.5 percentage points.
} 
timate for the effect of the triple interaction is marginally insignificant. ${ }^{19}$ The positive sign of the coefficient of this variable reinforces the conclusion that the widening gender gap regarding overtime payments is not related with changes in the gender distribution of overtime hours. Combining this result with the previous one on the probability of receiving benefits, it seems to be the case that the overall widening of the gender pay gap for minors is due to a redistribution of benefits and to a decrease in the price of overtime work for females.

Table 3: Regressions: overtime hours

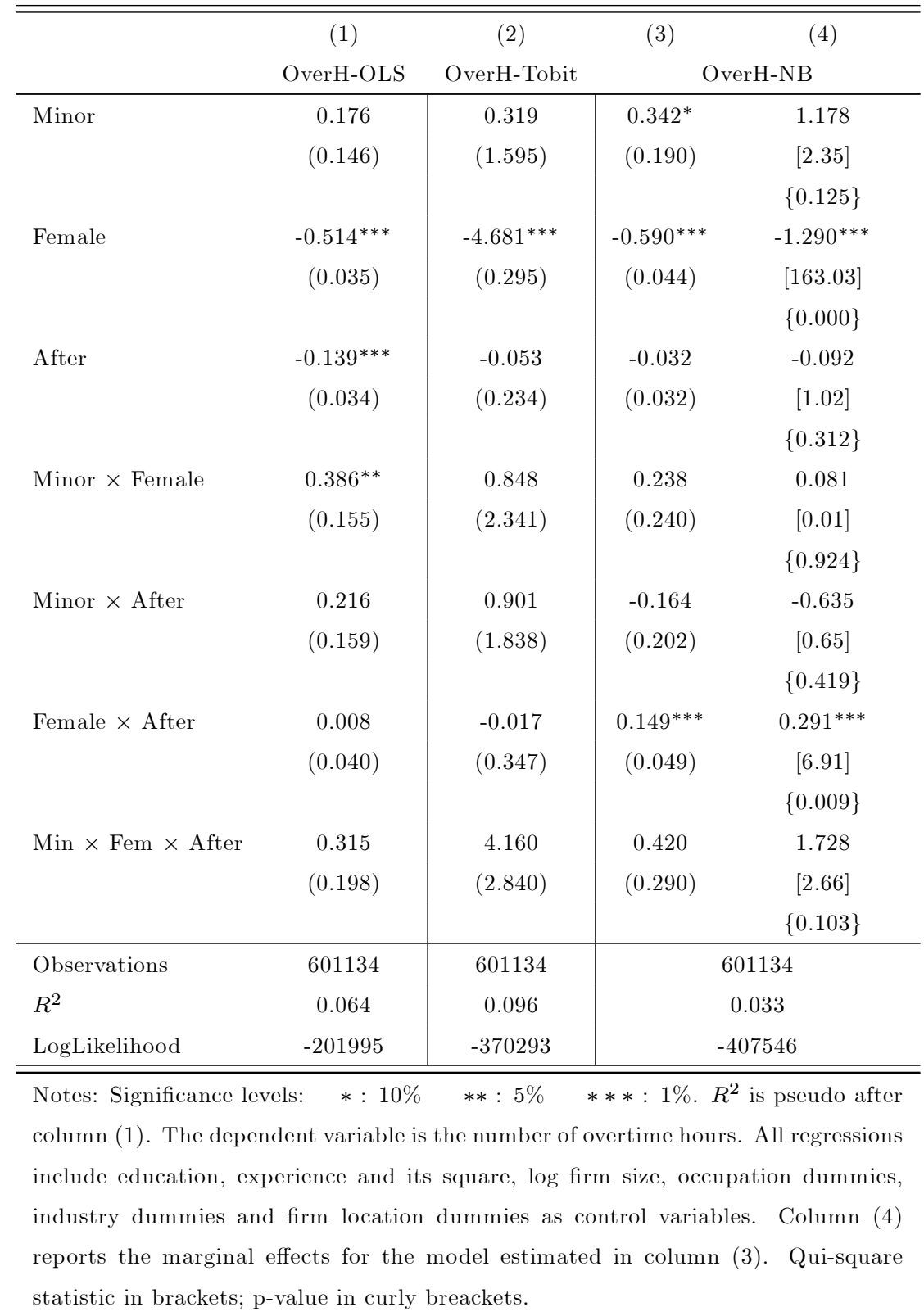

${ }^{19}$ The qui-squared statistic has a $p-v a l u e$ of 0.103 . 


\section{Robustness checks}

We will now discuss robustness checks on our main results. As discussed earlier, if the effect we detect using the DDD methodology is a result of the amendment to the law, we should not be able to detect the same effect for years without treatment. To check this, we apply placebo amendments to the other years in the panel. By doing so, we test whether the DDD methodology produces negative significant coefficients for the triple interaction term for the years when there was no increase in the MW. We run regressions based on equation (2) by replacing the dummy AFTER with AFTER taking the value 1 for the year $t$ of the placebo amendment and afterwards. We run each equation for two-year intervals, as we did for the main regressions. ${ }^{20}$ In each equation, the dependent variable is the log hourly real total wage.

Looking at Table 4, there is not a single year where we detect a significant coefficient for the triple interaction term. This conclusion remains almost the same when we use the whole adult workforce as the control group, which has a much more stable gender gap over the years (see Table 13 in the Appendix). The coefficient for the triple interaction for 1998 indicates a 3.0 percentage points increase in the gender gap for the minors, while we do not detect a negative significant coefficient for the other years. This set of results reinforce our conclusion in the previous section: the law amendment that occurred in 1998 is associated with an increase in the wage gap for minors.

\footnotetext{
${ }^{20}$ Due to data unavailability for 2001 , the placebo amendment for 2000 is based only on 1999 and 2000 data; and the placebo for 2002 compares the years 2000 and 2002. Similarly, the placebo for 1997 does not include 1998 data, as this is the year of the amendment.
} 


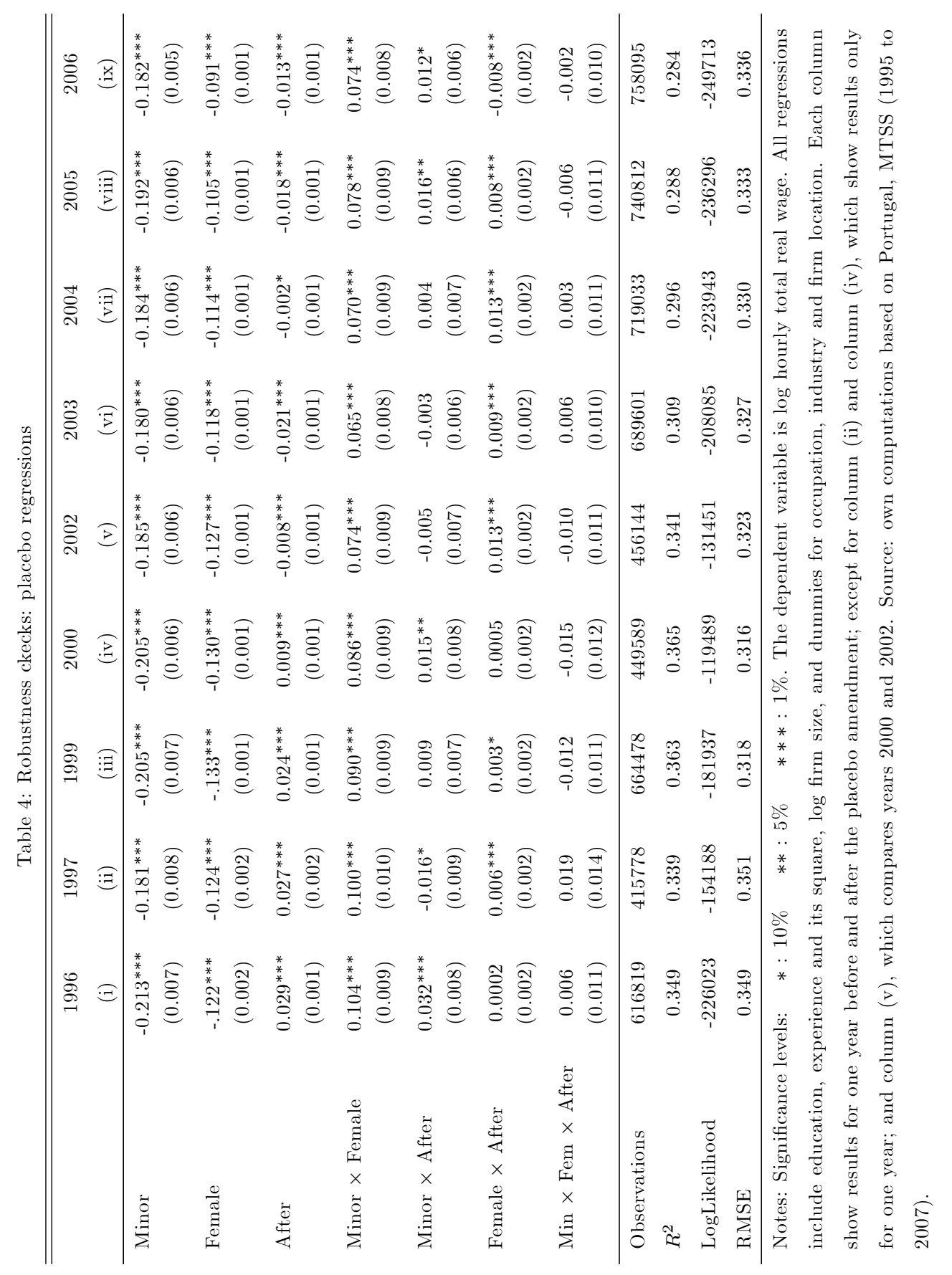


A second robustness check follows Averett and Hotchkiss (1995) and Oyer (2008). They establish a link between benefits and working hours. In case of a positive link between the two, one may still assert that the increasing gender gap for hourly wages after the amendment may be a result of long term decrease in the working hours of the minor females more pronounced than for minor males, instead of being the effect of the amendment. To control for this, we run equation (2) for total wage including log of actual working hours as explanatory variable. The results are reported in Table 5. Despite the fact that benefits and working hours are correlated, the coefficient of the triple interaction term is still significant with a value of -0.03 in both hourly and monthly equations, meaning that the results we obtained are robust even after controlling for working hours.

Table 5: Robustness ckecks: controlling for working hours

\begin{tabular}{lcccc}
\hline \hline & $\begin{array}{c}\text { Hourly Total } \\
\text { Wage }\end{array}$ & $\begin{array}{c}\text { Monthly Total } \\
\text { Wage }\end{array}$ & $\begin{array}{c}\text { Hourly } \\
\text { Benefits }\end{array}$ & $\begin{array}{c}\text { Monthly } \\
\text { Benefits }\end{array}$ \\
\hline Log Hours & $-0.247^{* * *}$ & $0.753^{* * *}$ & $-0.490^{* * *}$ & $0.485^{* * *}$ \\
& $(0.001)$ & $(0.001)$ & $(0.005)$ & $(0.005)$ \\
Min $\times$ Fem $\times$ After & $-0.030^{* * *}$ & $-0.030^{* * *}$ & $-0.065^{*}$ & $-0.067^{* *}$ \\
& $(0.010)$ & $(0.010)$ & $(0.034)$ & $(0.034)$ \\
\hline $\begin{array}{l}\text { Observations } \\
R^{2}\end{array}$ & 659133 & 659133 & 444763 & 444763 \\
LogLikelihood & 0.384 & 0.491 & 0.179 & 0.169 \\
RMSE & -188470 & -188470 & -558463 & -557736 \\
\hline $\begin{array}{l}\text { Notes: Significance levels: } \\
\text { experience and its square, log firm size, and dummies for occupation, industry and firm location. } \\
\text { Source: own computations based on Portugal, MTSS (1995 to 2007). }\end{array}$
\end{tabular}

These robustness checks show that the significant widening in the gender gap for the minor employees after the 1998 amendment is specific to that year and it remains even if we use an alternative control group. The increase in the gap was not a result of long-term reduction in the working hours of minor females. We will now discuss 
the possible channels that may have caused the gender gap to increase in extra income components.

\section{The increase in gender gap: possible explanations}

Previously we discussed three possible channels that may lead a MW increase to widen the gender gap at the total wage level. We can summarize these channels as (i) a change in the skill composition of the working males and females after the increase in the minimum wage, (ii) industrial and/or occupational differences in response to the changes in the wage floor and (iii) discrimination. In this section we explore the explanatory power of these channels for the case of the 1998 amendment. For the first channel, we follow a two-stage strategy. In the first stage we estimate a fixed-effects wage regression to obtain a measure for the individuals' time invariant skills. In the second stage we test whether there is a significant relative change in the individual time invariant skills of minor females who entered the labor market after the amendment. To test the validity of the second and the third channels, we divide the panel in subindustries and run our wage regressions to evaluate the effect of the amendment in each of them.

Starting with the first channel, we estimate the following wage equation for the whole panel with data between 1995 and 2007:

$$
\mathrm{W}_{i t}=\beta_{0}+\beta_{1} \mathrm{X}_{i t}+\eta_{i}+\varepsilon_{i t},
$$

where $\mathrm{W}_{i t}$ is the total log hourly real wage; $\mathrm{X}_{i t}$ is the vector of control variables including experience squared and log firm size, as well as dummies for years 1996 to 2007, industries, locations and occupations; $\eta_{i}$ is the individual time inavariant skills measure. Our aim is to check whether the average individual skills for the female minors who entered the workforce after the amendment are relatively lower than the average of those who entered before the amendment. To do so, we estimate a second stage equation, where the dependent variable is the estimated $\eta_{i}$ : 


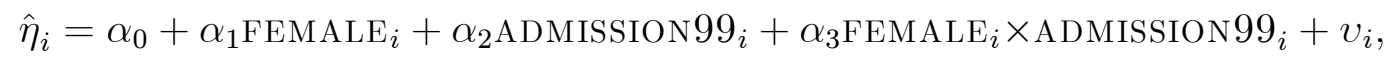

where ADMISSIOn99 is 1 for entrants in 1999, 0 otherwise. Equation (4) is estimated for minors who entered the workforce in 1997 and 1999. The $t$ test on $\alpha_{3}$ allows to test weather there is a significant change in the relative individual characteristics of the minor females compared to males, between those two years.

Table 6: Change in the skill composition - estimation results

\begin{tabular}{lcc}
\hline \hline & Coefficient & St. Error \\
\hline FEMALE & $-0.144^{* * *}$ & $(0.007)$ \\
ADMISSION99 & $-0.051^{* * *}$ & $(0.007)$ \\
FEMALE $\times$ ADMISSION99 & 0.008 & $(0.010)$ \\
\hline Observations & 9175 \\
$R^{2}$ & 0.085 \\
RMSE & 0.240 \\
\hline Notes: Significance level: & $* * *: 1 \%$. The dependent variable \\
is the individual fixed effect. Source: own computations based \\
on Portugal, MTSS (1995 to 2007).
\end{tabular}

There is a decrease in the average individual skills for minors entering the labor market after 1997, which is not, however, different between males and females (see Table 6 ) - the coefficient of FEMALE $\times$ ADMISSION99 does not indicate a relative change in female individual skills. The general increasing trend in schooling for minors is a possible explanation for the first result as less skilled minors could enter earlier in the labor market.

We now investigate the explanatory power of the remaining two possibilities. We conduct similar analyses to the previous section for separate industries. In 1997, the year before the amendment, about $86 \%$ of minor workers were concentrated in four industries: textiles, other manufacturing, construction, and wholesale and retail trade 
(see Table 9 in the Appendix). ${ }^{21}$ There is a visible concentration of females in textiles (73.3\% of minor employees). In construction, other manufacturing and wholesale and retail the shares were $1.3 \%, 21.5 \%$ and $31.2 \%$, respectively.
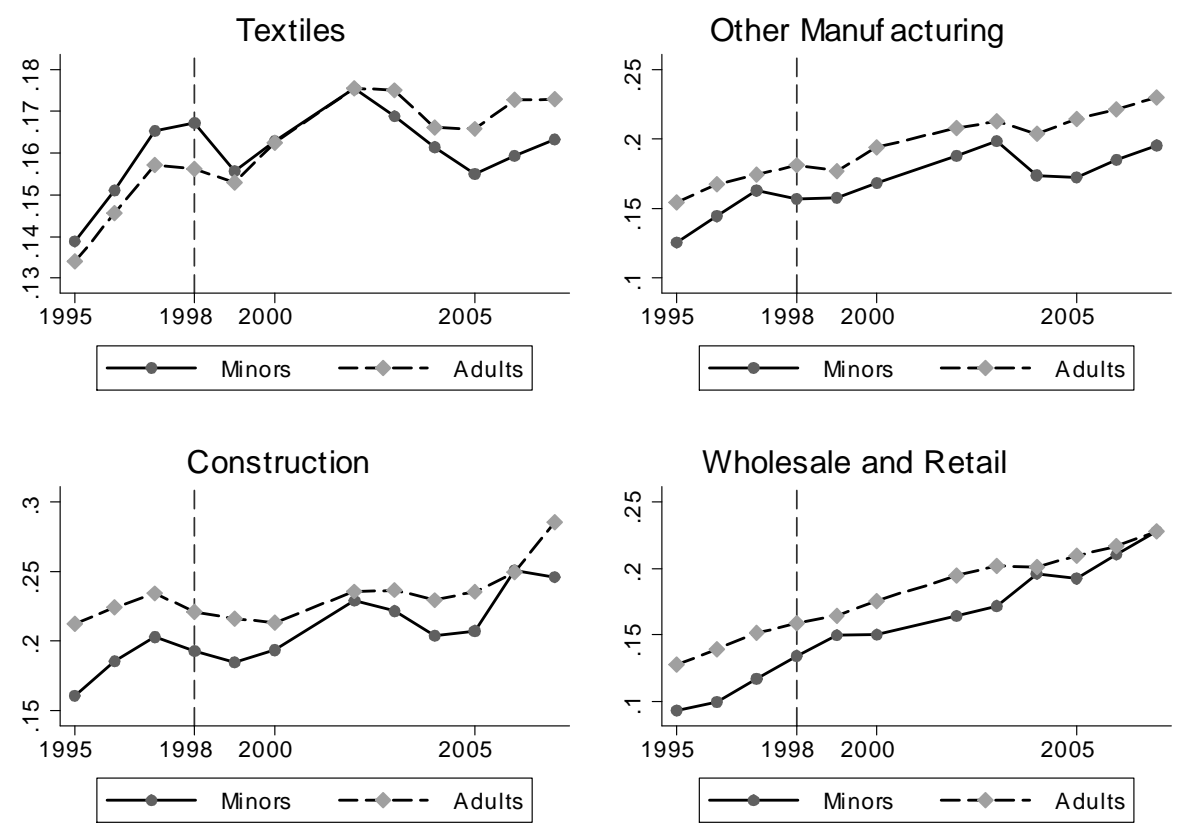

Figure 4: Note: average differences between the full and the base wages by industries (in log points). Source: own computations based on Portugal, MTSS (1995 to 2007).

There are some reasons why fringe benefits and overtime payments might have reacted differently across industries to the raise in the MW. Firstly, the textiles was the most affected industry by the amendment, because of the higher share of the minor employees among its labor force. Secondly, the textiles industry was the only sector where the relative difference between total and base wage was higher for minors, until 2000 - see Figure 4. Thirdly, the textiles industry was already under pressure by increasing international competition, especially from China. Therefore, employers could mitigate the effect of the MW increase on operating costs by reducing the extra-payments component. It is clear from Figure 4 that the gap between adults and minors in these industries narrowed considerably after 1998.

\footnotetext{
${ }^{21}$ Textiles include textiles, wearing apparel and leather products. Other manufacturing includes wood, cork, and paper manufacturing, metallic and non-metallic products and furniture. Wholesale and retail trade includes wholesale and retail trade, repairments, as well as hotels and restaurants.
} 


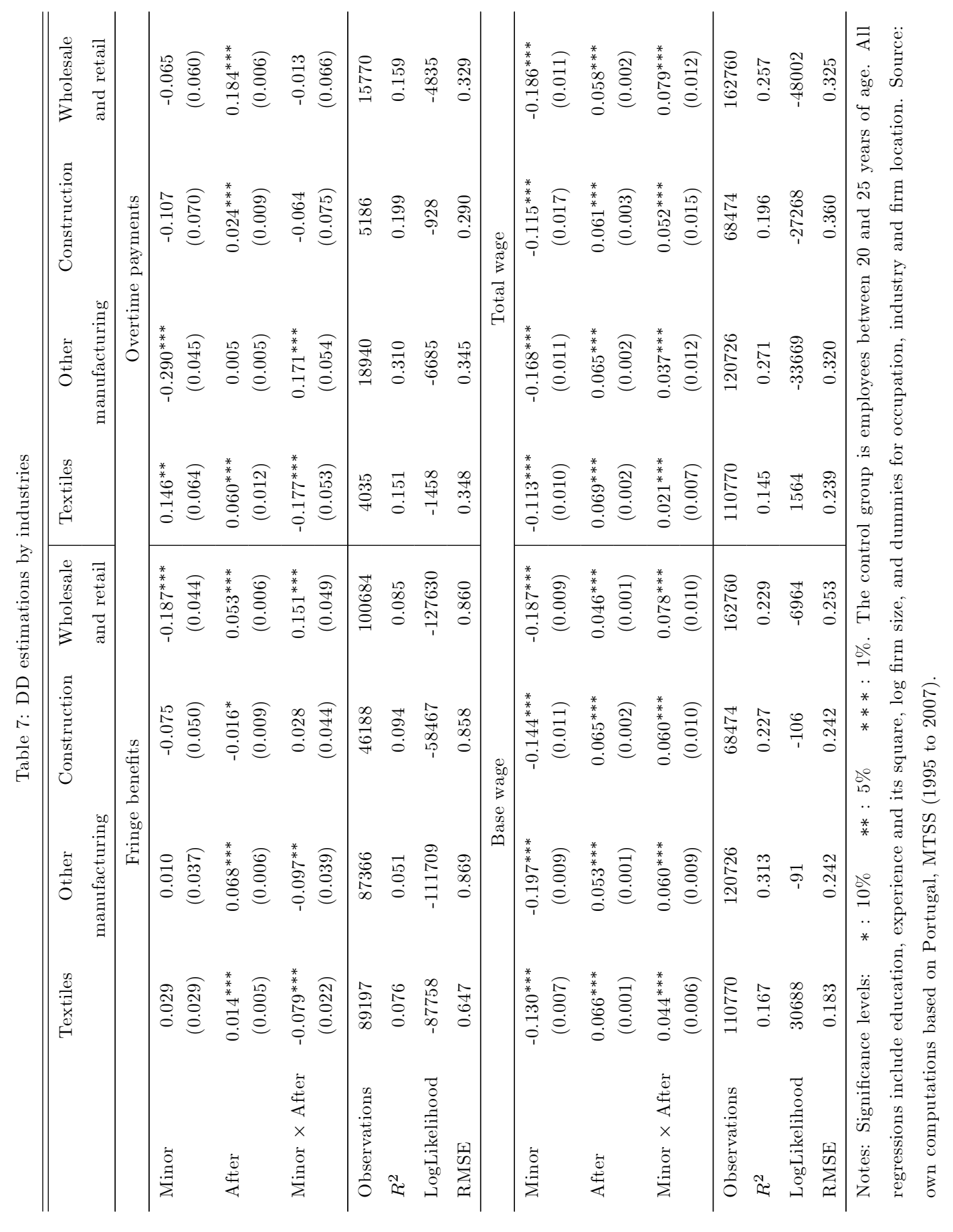


Table 7 reports the estimation results for changes in the base wages, overtime payments, benefits and total wages, for each of these industry categories for the minor workers (excluding the gender dimension). ${ }^{22}$ The results show that there are clear differences in adjustments of fringe benefits and overtime payments after the MW increase among industries. In textiles, as well as in construction, there are significant reductions in the minors' extra income components after the amendment. The effect is stronger for Textiles. As a result, the total wage increase of 2.1 percentage points for minors in textiles remained the lowest (see Table 7).

The small increase in wages for this female-concentrated industry provides an explanation for the widening gap after the amendment. This explanation, however, does not eliminate the possibility of redistribution of fringe benefits from female to male workers within industries. To test this, we estimate equation (2) for each industry and report the results in Table $8 .^{23}$ There is no increase in the minor gender gap within textiles after the amendment, and the increase in the manufacturing is not statistically significant. However, there is a significant and very strong (5.2 percentage points) increase in the gap within the wholesale and retail industry.

The interpretation of the latter result in the gender gap is not straightforward. Assuming that there are no structural differences among the sub-sectors of wholesale and retail industry and considering very similar individual characteristics of this group of workers because of their age, an institutional explanation to the widening gender gap would be the discrimination against females. If the amendment had increased the MW to a level that mostly male employees were considered to be privileged for, employers might have used the extra components of income to create the wage hierarchy they desired.

${ }^{22}$ The equation is a variation of equation (2):

$$
W_{i t}=\beta_{0}+\beta_{1} \operatorname{Minor}_{i}+\beta_{2} \operatorname{AFTER} 8_{t}+\beta_{5} \operatorname{Minor}_{i} \times \operatorname{AFTER} 98_{t}+\beta_{3} \mathrm{X}_{i t}+\varepsilon_{i t},
$$

where $X$ excludes industrial dummies. The control group is composed by the 20 to 25 year old employees.

${ }^{23}$ We exclude construction, as the total number of minor females in this industry was only 20. 
Table 8: DDD estimations for each industry

\begin{tabular}{|c|c|c|c|}
\hline & $\begin{array}{l}\text { Textiles } \\
\text { (i) }\end{array}$ & $\begin{array}{l}\text { Other } \\
\text { manufacturing } \\
\text { (ii) }\end{array}$ & $\begin{array}{l}\text { Wholesale } \\
\text { and retail } \\
\text { (iii) }\end{array}$ \\
\hline Minor & $\begin{array}{c}-0.169^{* * *} \\
(0.014)\end{array}$ & $\begin{array}{c}-0.222^{* * *} \\
(0.012)\end{array}$ & $\begin{array}{c}-0.251^{* * *} \\
(0.014)\end{array}$ \\
\hline Female & $\begin{array}{c}-0.136^{* * *} \\
(0.003)\end{array}$ & $\begin{array}{c}-0.161^{* * *} \\
(0.003)\end{array}$ & $\begin{array}{c}-0.083^{* * *} \\
(0.003)\end{array}$ \\
\hline After & $\begin{array}{c}0.070^{* * *} \\
(0.003)\end{array}$ & $\begin{array}{c}0.076^{* * *} \\
(0.002)\end{array}$ & $\begin{array}{c}0.070^{* * *} \\
(0.002)\end{array}$ \\
\hline Minor $\times$ Female & $\begin{array}{c}0.068^{* * *} \\
(0.014)\end{array}$ & $\begin{array}{c}0.124^{* * *} \\
(0.020)\end{array}$ & $\begin{array}{c}0.159^{* * *} \\
(0.021)\end{array}$ \\
\hline Minor $\times$ After & $\begin{array}{l}0.011 \\
(0.015)\end{array}$ & $\begin{array}{c}0.037^{* * *} \\
(0.014)\end{array}$ & $\begin{array}{c}0.090^{* * *} \\
(0.016)\end{array}$ \\
\hline Female $\times$ After & $\begin{array}{c}-0.0008 \\
(0.003)\end{array}$ & $\begin{array}{c}-0.025^{* * *} \\
(0.004)\end{array}$ & $\begin{array}{c}-0.022^{* * *} \\
(0.003)\end{array}$ \\
\hline Min $\times$ Fem $\times$ After & $\begin{array}{l}0.009 \\
(0.017)\end{array}$ & $\begin{array}{l}-0.019 \\
(0.026)\end{array}$ & $\begin{array}{c}-0.052^{* *} \\
(0.025)\end{array}$ \\
\hline Observations & 110770 & 120726 & 162760 \\
\hline$R^{2}$ & 0.188 & 0.314 & 0.27 \\
\hline LogLikelihood & 4388.14 & -29989.99 & -46557.80 \\
\hline RMSE & 0.233 & 0.310 & 0.322 \\
\hline $\begin{array}{l}\text { Notes: Significance levels: } \\
\text { dependent variable is log } 1 \\
\text { education, experience and } \\
\text { cupation, industry and fir } \\
\text { on Portugal, MTSS (1995 }\end{array}$ & $\begin{array}{l}\quad *: 10 \% \\
\text { hourly real to } \\
\text { its square, lo } \\
\text { m location. S } \\
\text { to } 2007) \text {. }\end{array}$ & $\begin{array}{l}* *: 5 \% \quad * * * \\
\text { al wage. All regress } \\
\text { firm size, and dum } \\
\text { ource: own computa }\end{array}$ & $\begin{array}{l}: 1 \% . \text { The } \\
\text { ons include } \\
\text { mies for oc- } \\
\text { tions based }\end{array}$ \\
\hline
\end{tabular}

Based on these results we conclude that industrial differences in the flexibility of extra income payments was an important source of the increasing gender gap after the amendment. In the textiles industry, where the minors have a higher share compared to the other industries, employers responded to the MW increase with significant reductions in overtime payments and fringe benefits. As a result, the increase in the total wages in the textiles remained smaller when compared to the increase registered in the other industries, which is not surprising due to its high degree of openness to 
international trade. A secondary source for the increase in the gender gap might have been the differentiation of male and female wages within the wholesale and retail industry, industries of the non-tradable goods sector, where employers may opt to adjust mark-up ratios if reducing extra payments have productivity costs.

\section{Conclusion}

This paper provides new insights on the gender wage gap following an increase in minimum wage, and relates it to the distribution of fringe benefits and overtime payments. We use matched employer-employee data on the Portuguese labor market and benefit from a quasi-natural experiment provided by a nation-wide increase in the minor employees' minimum wage in 1998. We conducted separate analysis for base wage, overtime payments and fringe benefits, as well as for the amount of overtime work. Estimation results based on a difference-in-difference-in-differences methodology show a widening of the gender gap among minor workers following the amendment, explained mainly by a redistribution of fringe benefits and overtime payments in favor of males.

We explore three possible channels of redistribution, namely, discrimination, asymmetric changes in the skill composition of male and female employees as a result of the minimum wage increase, and differences in the flexibility of extra payments among industries where females have different shares. The analysis at the industry level shows that inter-industry differences in flexibility of adjustment of fringe benefits and overtime payments contribute to the increasing gap. We also observe an increase in the unexplained gender gap within wholesale and retail industry, which may indicate discrimination as a contributing factor.

Summing up, the distribution of fringe benefits and overtime payments are not gender-neutral. Contrary to the findings of previous studies on the U.S. labor market, we find that the gender gap becomes wider when we account for extra components of income. The equalizing impact of the minimum wage increase on the gender gap is not warranted as long as there is industry crowding and different competitive environments, and substantial differences across these industries in the adjustment of extra components of income. 


\section{References}

Ahn, Thomas, Peter Arcidiacono and Walter Wessels (2011), 'The distributional impacts of minimum wage increases when both labor supply and labor demand are endogenous', Journal of Business and Economic Statistics 29(1), 12-23.

Almeida, Maria dos Anjos (2008), Salário minimo: de 1974 aos dias de hoje, Observatório do Emprego e Formação Profissional; Lisbon.

Arulampalam, Wiji, Alison L. Booth and Mark L. Bryan (2007), 'Is there a glass ceiling over europe? Exploring the gender pay gap across the wage distribution', Industrial and Labor Relations Review 60(2), 163-186.

Averett, Susan L. and Julie L. Hotchkiss (1995), 'The probability of receiving benefits at different hours of work', The American Economic Review 85(2), 276-280.

Card, David E. and Alan B. Krueger (1995), Myth and measurement: the new economics of the minimum wage, Princeton University Press, Princeton ; Chichester.

Cerejeira, João (2008), 'Young employment, job-skill composition and minimum wages: evidence from a 'natural experiment", NIPE WP 4/2008.

Giuliano, Laura (2011), 'Effects of the 1996 federal minimum wage law on employment, substitution, and the teenage labor supply: evidence from personnel data', Journal of Labor Economics Forthcoming.

Grossberg, Adam J. and Paul Sicilian (2004), 'Legal minimum wages and employment duration', Southern Economic Journal 70(3), 631-645.

Holzer, Harry J., Lawrence F. Katz and Alan B. Krueger (1991), 'Job queues and wages', The Quarterly Journal of Economics 106(3), 739-768.

Lowen, Aaron and Paul Sicilian (2009), 'Family-friendly fringe benefits and the gender wage gap', Journal of Labor Research 30(2), 101-119.

Meyer, Robert H and David A Wise (1983), 'Discontinuous distributions and missing persons: the minimum wage and unemployed youth', Econometrica 51(6), 1677-98.

Neumark, David and William L. Wascher (2007), 'Minimum wages and employment', Foundations and Trends in Microeconomics 3(1+2), 1-182. 
Oyer, Paul (2008), 'Salary or benefits?', Research in Labor Economics 28, 429-467.

Portugal, Ministério do Trabalho e da Segurança Social (MTSS) (1995 to 2007), Quadros de Pessoal. Data in magnetic media.

Robinson, Helen (2002), 'Wrong side of the track? The impact of the minimum wage on gender pay gaps in Britain', Oxford Bulletin of Economics and Statistics 64(5), 417-48.

Robinson, Helen (2005), 'Regional evidence on the effect of the national minimum wage on the gender pay gap', Regional Studies 39(7), 855-872.

Shannon, Michael (1996), 'Minimum wages and the gender wage gap', Applied Economics 28(12), 1567-76.

Sicilian, Paul and Adam J. Grossberg (1993), 'Do legal minimum wages create rents? A re-examination of the evidence', Southern Economic Journal 60(1), 201-209.

Simon, Kosali Ilayperuma and Robert Kaestner (2004), 'Do minimum wages affect non-wage job attributes? Evidence on fringe benefits', Industrial and Labor Relations Review $\mathbf{5 8}(1), 52-70$.

Solberg, Eric and Teresa Laughlin (1995), 'The gender pay gap, fringe benefits, and occupational crowding', Industrial and Labor Relations Review 48(4), 692-708.

Wessels, Walter J. (1980), Minimum wages, fringe benefits, and working conditions, American Enterprise Institute for Public Policy Research, Washington. 


\section{Appendix}

Table 9: Employment by major industries before and after the amendment

\begin{tabular}{|c|c|c|c|c|c|c|c|c|}
\hline & \multicolumn{4}{|c|}{1997} & \multicolumn{4}{|c|}{1999} \\
\hline & \multicolumn{2}{|c|}{ Total } & \multicolumn{2}{|c|}{ Minors Only } & \multicolumn{2}{|c|}{ Total } & \multicolumn{2}{|c|}{ Minors Only } \\
\hline & $\begin{array}{c}\text { Number } \\
\text { (i) }\end{array}$ & $\begin{array}{c}\% \text { Females } \\
\text { (ii) }\end{array}$ & $\begin{array}{c}\text { Number } \\
\text { (iii) }\end{array}$ & $\begin{array}{c}\% \text { Females } \\
\text { (iv) }\end{array}$ & $\begin{array}{c}\text { Number } \\
(\mathrm{v})\end{array}$ & $\begin{array}{c}\% \text { Females } \\
\text { (vi) }\end{array}$ & $\begin{array}{c}\text { Number } \\
\text { (vii) }\end{array}$ & $\begin{array}{c}\% \text { Females } \\
\text { (viii) }\end{array}$ \\
\hline Textiles & 266656 & 69.96 & 5124 & 73.32 & 261259 & 70.55 & 3331 & 73.85 \\
\hline$\%$ Total Employment & 13.84 & 23.72 & 38.09 & 63.66 & 12.45 & 20.98 & 32.01 & 55.39 \\
\hline Other manufactures & 381070 & 27.53 & 2925 & 21.47 & 406115 & 29.19 & 1962 & 17.38 \\
\hline$\%$ Total Employment & 19.78 & 13.34 & 21.74 & 10.64 & 19.35 & 13.49 & 18.85 & 7.68 \\
\hline Construction & 198645 & 7.16 & 1736 & 1.32 & 223213 & 7.76 & 1558 & 1.35 \\
\hline$\%$ Total Employment & 10.31 & 1.81 & 12.91 & 0.39 & 10.64 & 1.97 & 14.97 & 0.47 \\
\hline Wholesale and retail & 395234 & 40.09 & 1771 & 31.17 & 434720 & 41.97 & 1657 & 37.78 \\
\hline$\%$ Total Employment & 20.52 & 20.15 & 13.17 & 9.35 & 20.72 & 20.76 & 15.92 & 14.10 \\
\hline
\end{tabular}

Source: own computations based on Portugal, MTSS (1995 to 2007).

Table 10: Shares of extra income receivers

\begin{tabular}{|c|c|c|c|c|c|c|c|c|}
\hline & \multicolumn{4}{|c|}{ Adults } & \multicolumn{4}{|c|}{ Minors } \\
\hline & \multicolumn{2}{|c|}{ Males } & \multicolumn{2}{|c|}{ Females } & \multicolumn{2}{|c|}{ Males } & \multicolumn{2}{|c|}{ Females } \\
\hline & $\begin{array}{l}\text { Overtime } \\
\text { workers } \\
\text { (i) }\end{array}$ & $\begin{array}{l}\text { Benefit } \\
\text { receivers } \\
\text { (ii) }\end{array}$ & $\begin{array}{c}\text { Overtime } \\
\text { workers } \\
\text { (iii) }\end{array}$ & $\begin{array}{c}\text { Benefit } \\
\text { receivers } \\
\text { (iv) }\end{array}$ & $\begin{array}{c}\text { Overtime } \\
\text { workers } \\
(\mathrm{v})\end{array}$ & $\begin{array}{c}\text { Benefit } \\
\text { receivers } \\
\text { (vi) }\end{array}$ & $\begin{array}{c}\text { Overtime } \\
\text { workers } \\
\text { (vii) }\end{array}$ & $\begin{array}{c}\text { Benefit } \\
\text { receivers } \\
\text { (viii) }\end{array}$ \\
\hline 1995 & 0.086 & 0.581 & 0.048 & 0.537 & 0.019 & 0.498 & 0.026 & 0.613 \\
\hline 1996 & 0.087 & 0.592 & 0.051 & 0.542 & 0.022 & 0.488 & 0.039 & 0.565 \\
\hline 1997 & 0.092 & 0.617 & 0.054 & 0.575 & 0.033 & 0.574 & 0.031 & 0.675 \\
\hline 1998 & 0.094 & 0.630 & 0.056 & 0.587 & 0.035 & 0.590 & 0.044 & 0.673 \\
\hline 1999 & 0.085 & 0.630 & 0.055 & 0.590 & 0.038 & 0.604 & 0.052 & 0.652 \\
\hline 2000 & 0.096 & 0.657 & 0.067 & 0.632 & 0.048 & 0.627 & 0.077 & 0.656 \\
\hline 2002 & 0.093 & 0.674 & 0.064 & 0.656 & 0.054 & 0.666 & 0.082 & 0.668 \\
\hline 2003 & 0.092 & 0.690 & 0.063 & 0.671 & 0.057 & 0.682 & 0.074 & 0.704 \\
\hline 2004 & 0.099 & 0.698 & 0.068 & 0.679 & 0.061 & 0.696 & 0.077 & 0.713 \\
\hline 2005 & 0.102 & 0.700 & 0.072 & 0.674 & 0.062 & 0.700 & 0.076 & 0.695 \\
\hline 2006 & 0.100 & 0.706 & 0.066 & 0.676 & 0.064 & 0.709 & 0.062 & 0.706 \\
\hline 2007 & 0.099 & 0.712 & 0.067 & 0.687 & 0.063 & 0.724 & 0.061 & 0.708 \\
\hline
\end{tabular}

Source: own computations based on Portugal, MTSS (1995 to 2007). 
Table 11: Means and standard-deviations of individual characteristics

\begin{tabular}{|c|c|c|c|c|c|c|}
\hline & \multicolumn{3}{|c|}{ Adults } & \multicolumn{3}{|c|}{ Minors } \\
\hline & $\begin{array}{c}\text { Education } \\
\text { (i) }\end{array}$ & $\begin{array}{l}\text { Age } \\
\text { (ii) }\end{array}$ & $\begin{array}{c}\text { Experience } \\
\text { (iii) }\end{array}$ & $\begin{array}{c}\text { Education } \\
\text { (iv) }\end{array}$ & $\begin{array}{l}\text { Age } \\
(\mathrm{v})\end{array}$ & $\begin{array}{c}\text { Experience } \\
\text { (vi) }\end{array}$ \\
\hline 1995 & $\begin{array}{c}6.626 \\
(3.536)\end{array}$ & $\begin{array}{c}37.476 \\
(11.640)\end{array}$ & $\begin{array}{c}20.941 \\
(11.801)\end{array}$ & $\begin{array}{c}5.647 \\
(1.562)\end{array}$ & $\begin{array}{l}17.175 \\
(0.605)\end{array}$ & $\begin{array}{c}1.253 \\
(0.502)\end{array}$ \\
\hline 1996 & $\begin{array}{c}6.782 \\
(3.588)\end{array}$ & $\begin{array}{c}37.684 \\
(11.616)\end{array}$ & $\begin{array}{c}21.108 \\
(11.804)\end{array}$ & $\begin{array}{c}5.896 \\
(1.736)\end{array}$ & $\begin{array}{l}17.233 \\
(0.552)\end{array}$ & $\begin{array}{c}1.275 \\
(0.492)\end{array}$ \\
\hline 1997 & $\begin{array}{c}6.899 \\
(3.621)\end{array}$ & $\begin{array}{c}37.663 \\
(11.617)\end{array}$ & $\begin{array}{c}21.056 \\
(11.830)\end{array}$ & $\begin{array}{c}6.067 \\
(1.843)\end{array}$ & $\begin{array}{l}17.282 \\
(0.492)\end{array}$ & $\begin{array}{c}1.302 \\
(0.457)\end{array}$ \\
\hline 1998 & $\begin{array}{c}7.088 \\
(3.685)\end{array}$ & $\begin{array}{c}37.861 \\
(11.625)\end{array}$ & $\begin{array}{c}21.200 \\
(11.875)\end{array}$ & $\begin{array}{c}6.432 \\
(1.999)\end{array}$ & $\begin{array}{l}17.312 \\
(0.473)\end{array}$ & $\begin{array}{c}1.323 \\
(0.447)\end{array}$ \\
\hline 1999 & $\begin{array}{c}7.207 \\
(3.715)\end{array}$ & $\begin{array}{c}37.919 \\
(11.585)\end{array}$ & $\begin{array}{c}21.224 \\
(11.855)\end{array}$ & $\begin{array}{c}6.500 \\
(2.079)\end{array}$ & $\begin{array}{l}17.354 \\
(0.451)\end{array}$ & $\begin{array}{c}1.363 \\
(0.430)\end{array}$ \\
\hline 2000 & $\begin{array}{c}7.384 \\
(3.760)\end{array}$ & $\begin{array}{c}38.035 \\
(11.557)\end{array}$ & $\begin{array}{c}21.290 \\
(11.858)\end{array}$ & $\begin{array}{c}6.711 \\
(2.089)\end{array}$ & $\begin{array}{l}17.333 \\
(0.476)\end{array}$ & $\begin{array}{c}1.344 \\
(0.449)\end{array}$ \\
\hline 2002 & $\begin{array}{c}7.714 \\
(3.850)\end{array}$ & $\begin{array}{c}38.187 \\
(11.452)\end{array}$ & $\begin{array}{c}21.341 \\
(11.805)\end{array}$ & $\begin{array}{c}7.059 \\
(2.158)\end{array}$ & $\begin{array}{l}17.324 \\
(0.476)\end{array}$ & $\begin{array}{c}1.334 \\
(0.450)\end{array}$ \\
\hline 2003 & $\begin{array}{c}7.881 \\
(3.867)\end{array}$ & $\begin{array}{c}38.383 \\
(11.371)\end{array}$ & $\begin{array}{c}21.491 \\
(11.739)\end{array}$ & $\begin{array}{c}7.168 \\
(2.115)\end{array}$ & $\begin{array}{l}17.348 \\
(0.464)\end{array}$ & $\begin{array}{c}1.353 \\
(0.443)\end{array}$ \\
\hline 2004 & $\begin{array}{c}8.078 \\
(3.890)\end{array}$ & $\begin{array}{c}38.536 \\
(11.321)\end{array}$ & $\begin{array}{c}21.586 \\
(11.712)\end{array}$ & $\begin{array}{c}7.417 \\
(2.083)\end{array}$ & $\begin{array}{l}17.319 \\
(0.486)\end{array}$ & $\begin{array}{c}1.323 \\
(0.469)\end{array}$ \\
\hline 2005 & $\begin{array}{c}8.298 \\
(3.925)\end{array}$ & $\begin{array}{c}38.435 \\
(11.346)\end{array}$ & $\begin{array}{c}21.410 \\
(11.767)\end{array}$ & $\begin{array}{c}7.538 \\
(2.102)\end{array}$ & $\begin{array}{l}17.305 \\
(0.479)\end{array}$ & $\begin{array}{c}1.305 \\
(0.468)\end{array}$ \\
\hline 2006 & $\begin{array}{c}8.548 \\
(3.945)\end{array}$ & $\begin{array}{c}38.652 \\
(11.314)\end{array}$ & $\begin{array}{c}21.545 \\
(11.774)\end{array}$ & $\begin{array}{c}7.834 \\
(2.064)\end{array}$ & $\begin{array}{l}17.312 \\
(0.485)\end{array}$ & $\begin{array}{c}1.307 \\
(0.480)\end{array}$ \\
\hline 2007 & $\begin{array}{c}8.752 \\
(3.957)\end{array}$ & $\begin{array}{c}38.879 \\
(11.336)\end{array}$ & $\begin{array}{c}21.703 \\
(11.829)\end{array}$ & $\begin{array}{c}7.994 \\
(2.083)\end{array}$ & $\begin{array}{l}17.322 \\
(0.489)\end{array}$ & $\begin{array}{c}1.313 \\
(0.478)\end{array}$ \\
\hline
\end{tabular}

Source: own computations based on Portugal, MTSS (1995 to 2007). 


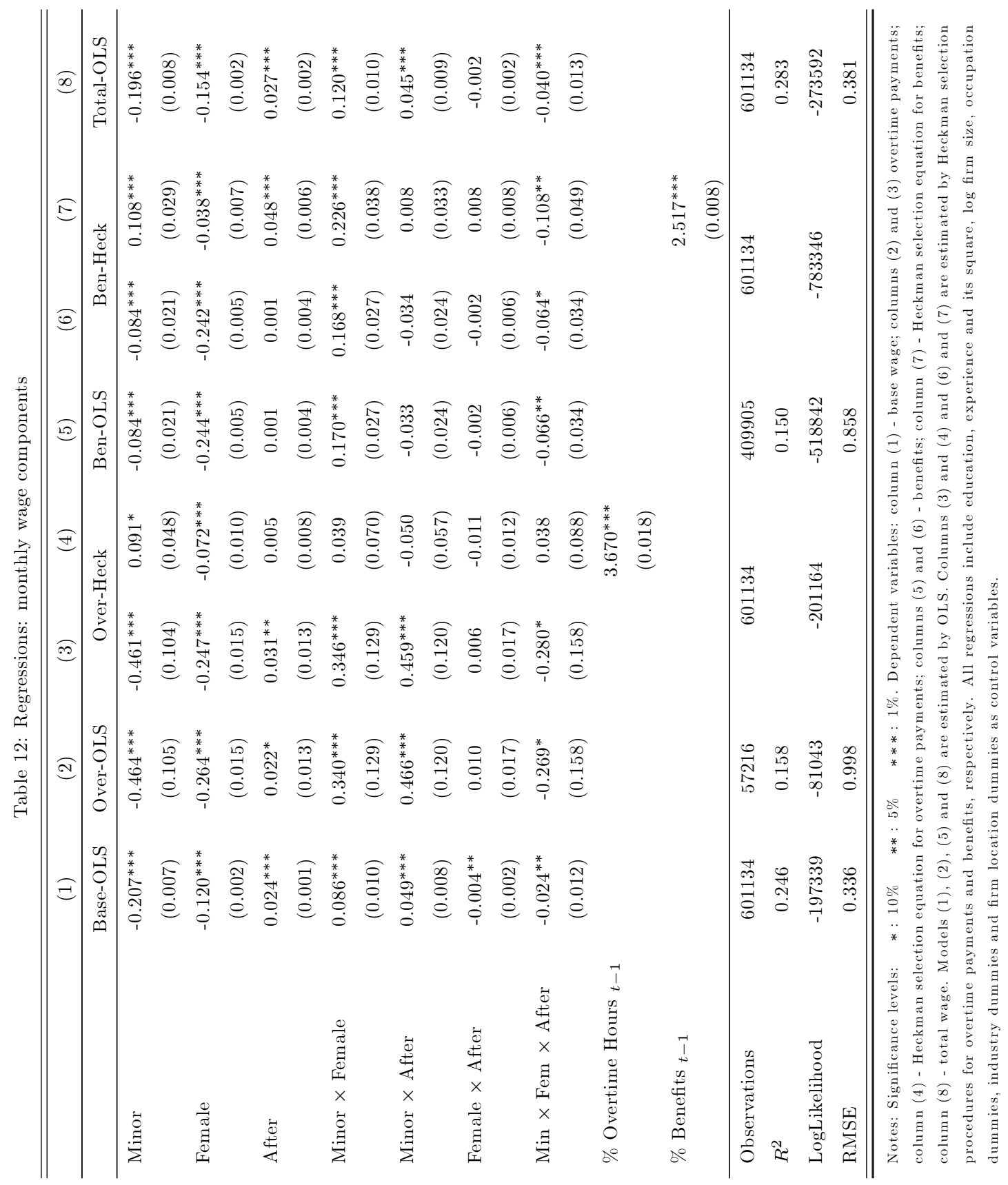




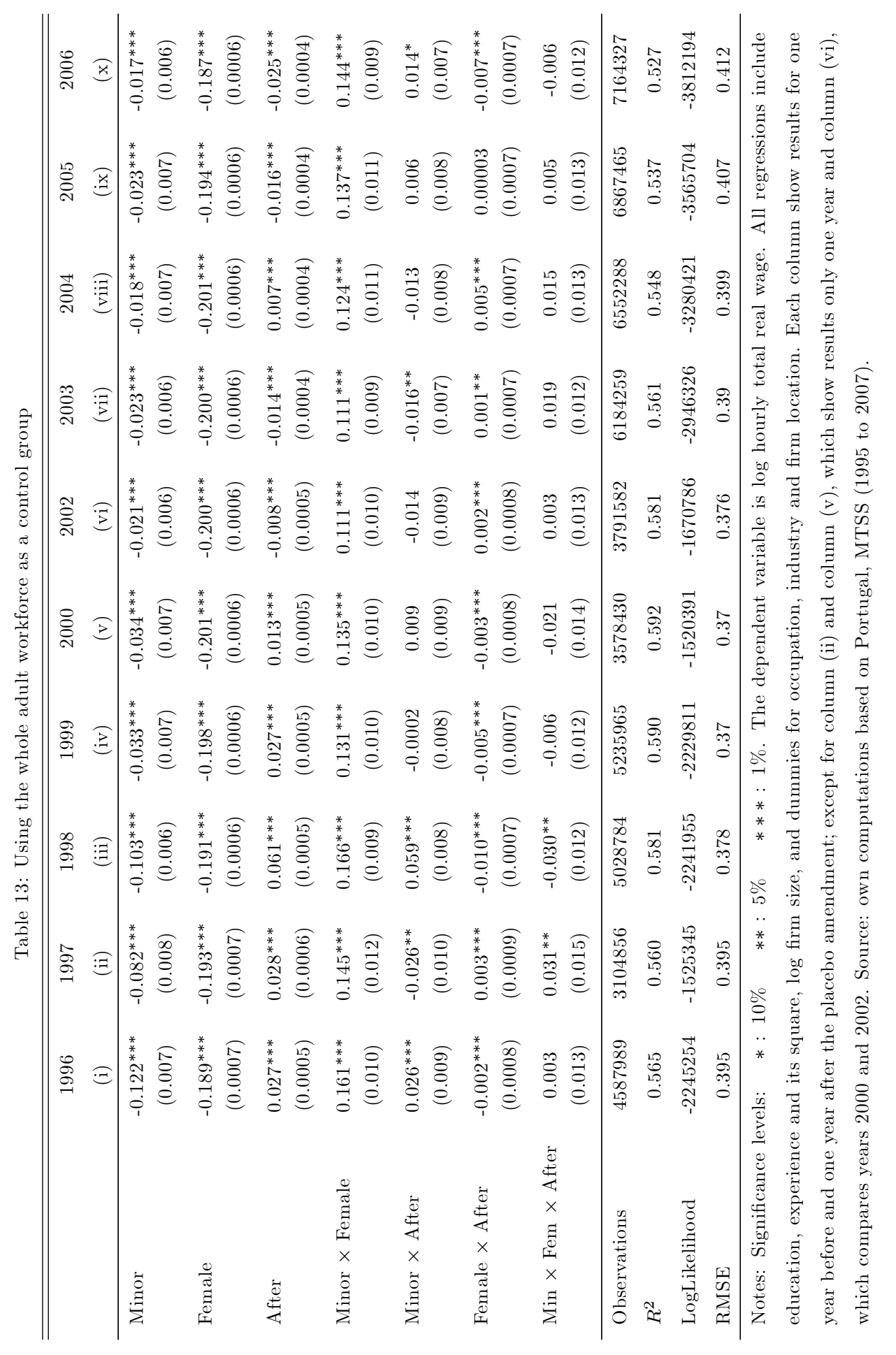




\section{Most Recent Working Paper}

NIPE WP Kizilca, Kemal, João Cerejeira, Miguel Portela e Carla Sá, "Minimum wage, fringe benefits,

$34 / 2010$

overtime payments and the gender wage gap", 2010

NIPE WP Martins, Rodrigo. e Francisco José Veiga , “ Economic Voting in Portuguese Municipal

33/2010 Elections ", 2010

NIPE WP Gabriel, Vasco J. e Pataaree Sangduan, “An Efficient Test of Fiscal Sustainability”, 2010

$32 / 2010$

NIPE WP Batini, Nicoletta, Vasco J. Gabriel, Paul Levine e Joseph Pearlman, “A Floating versus

$31 / 2010$

Managed Exchange Rate Regime in a DSGE Model of India", 2010

NIPE WP Gabriel, Vasco J. e Luis F. Martins, "The cost channel reconsidered: a comment using an

30/2010 identification-robust approach", 2010

NIPE WP Gabriel, Vasco J., Paul Levine, Joseph Pearlman e Bo Yang, “An Estimated DSGE Model of

29/2010 the Indian Economy", 2010

NIPE WP Gabriel, Vasco J. e Luis F. Martins, "Cointegration Tests Under Multiple Regime Shifts: An

28/2010 Application to the Stock Price-Dividend Relationship", 2010

NIPE WP Nogueira, Carlos Gama e Linda Gonçalves Veiga, “Economic determinants of citizens'

27/2010 support for the European Union", 2010

NIPE WP Castro, Vitor e Ricardo M. Sousa, "How Do Central Banks React to Wealth Composition and

26/2010 Asset Prices?", 2010

NIPE WP Agnello, Luca e Ricardo M. Sousa, "Fiscal Policy and Asset Prices", 2010

$25 / 2010$

NIPE WP

$24 / 2010$

NIPE WP

$23 / 2010$

NIPE WP

$22 / 2010$

NIPE WP

$21 / 2010$

NIPE WP

20/2010

Castro, V., "The duration of business cycle expansions and contractions: Are there change-

points in duration dependence?", 2010

NIPE WP

$19 / 2010$

NIPE WP

$18 / 2010$

NIPE WP

$17 / 2010$

Aguiar-Conraria e Maria Joana Soares, "The Continuous Wavelet Transform: A Primer*”,

2010

Alexandre, Fernando, Pedro Bação, João Cerejeira e Miguel Portela, "Manufacturing

employment and exchange rates in the Portuguese economy: the role of openness, technology

and labour market rigidity", 2010

Aguiar-Conraria, Luís, Manuel M. F. Martins e Maria Joana Soares, "The yield curve and the macro-economy across time and frequencies", 2010

NIPE WP

$16 / 2010$

Kurt Richard Brekke, Tor Helge Holmås e Odd Rune Straume, "Margins and Market Shares:

Pharmacy Incentives for Generic Substitution", 2010

Afonso, Óscar, Pedro Neves e Maria Thopmson, "Costly Investment, Complementarities,

International Technological-Knowledge Diffusion and the Skill Premium", 2010

Mourão, Paulo e Linda G. Veiga, "Elections, Fiscal Policy and Fiscal Illusion", 2010

NIPE WP

$15 / 2010$

NIPE WP

$14 / 2010$

Conraria, Luís A., Pedro C. Magalhães, Maria Joana Soares, "Synchronism in Electoral

Cycles: How United are the United States? ", 2010

NIPE WP

$13 / 2010$

Figueiredo, Adelaide, Fernanda Figueiredo, Natália Monteiro e Odd Rune Straume,

"Restructuring in privatised firms: a Statis approach", 2010

Sousa, Ricardo M., "Collateralizable Wealth, Asset Returns, and Systemic Risk: International

Evidence", 2010

NIPE WP

$12 / 2010$

Sousa, Ricardo M., "How do Consumption and Asset Returns React to Wealth Shocks?

Evidence from the U.S. and the U.K", 2010

NIPE WP

$11 / 2010$

Monteiro, Natália., Miguel Portela e Odd Rune Straume, "Firm ownership and rent sharing", 2010

NIPE WP

$10 / 2010$

Afonso, Oscar, Sara Monteiro e Maria Thompson., "A Growth Model for the Quadruple Helix

Innovation Theory ", 2010

NIPE WP

Veiga, Linda G.," Determinants of the assignment of E.U. funds to Portuguese municipalities",

2010

$9 / 2010$

Sousa, Ricardo M., "Time-Varying Expected Returns: Evidence from the U.S. and the U.K", 2010

Sousa, Ricardo M., "The consumption-wealth ratio and asset returns: The Euro Area, the UK

and the US", 2010 


\begin{tabular}{|c|l|}
\hline $\begin{array}{c}\text { NIPE WP } \\
8 / 2010\end{array}$ & $\begin{array}{l}\text { Bastos, Paulo, e Odd Rune Straume, "Globalization, product differentiation and wage } \\
\text { inequality", 2010 }\end{array}$ \\
\hline $\begin{array}{c}\text { NIPE WP } \\
7 / 2010\end{array}$ & Veiga, Linda, e Francisco José Veiga, “Intergovernmental fiscal transfers as pork barrel”, 2010 \\
\hline $\begin{array}{c}\text { NIPE WP } \\
6 / 2010\end{array}$ & Rui Nuno Baleiras, “Que mudanças na Política de Coesão para o horizonte 2020?”, 2010 \\
\hline $\begin{array}{c}\text { NIPE WP } \\
5 / 2010\end{array}$ & $\begin{array}{l}\text { Aisen, Ari, e Francisco José Veiga, "How does political instability affect economic growth?”, } \\
2010\end{array}$ \\
\hline $\begin{array}{c}\text { NIPE WP } \\
4 / 2010\end{array}$ & $\begin{array}{l}\text { Sá, Carla, Diana Amado Tavares, Elsa Justino, Alberto Amaral, "Higher education (related) } \\
\text { choices in Portugal: joint decisions on institution type and leaving home", 2010 }\end{array}$ \\
\hline $\begin{array}{c}\text { NIPE WP } \\
3 / 2010\end{array}$ & Esteves, Rosa-Branca, "Price Discrimination with Private and Imperfect Information ”, 2010 \\
\hline $\begin{array}{c}\text { NIPE WP } \\
2 / 2010\end{array}$ & $\begin{array}{l}\text { Alexandre, Fernando, Pedro Bação, João Cerejeira e Miguel Portela, "Employment, } \\
\text { exchange rates and labour market rigidity”, 2010 }\end{array}$ \\
\hline $\begin{array}{c}\text { NIPE WP } \\
1 / 2010\end{array}$ & $\begin{array}{l}\text { Aguiar-Conraria, Luís, Pedro C. Magalhães e Maria Joana Soares, "On Waves in War and } \\
\text { Elections - Wavelet Analysis of Political Time-Series”, 2010 }\end{array}$ \\
\hline
\end{tabular}

